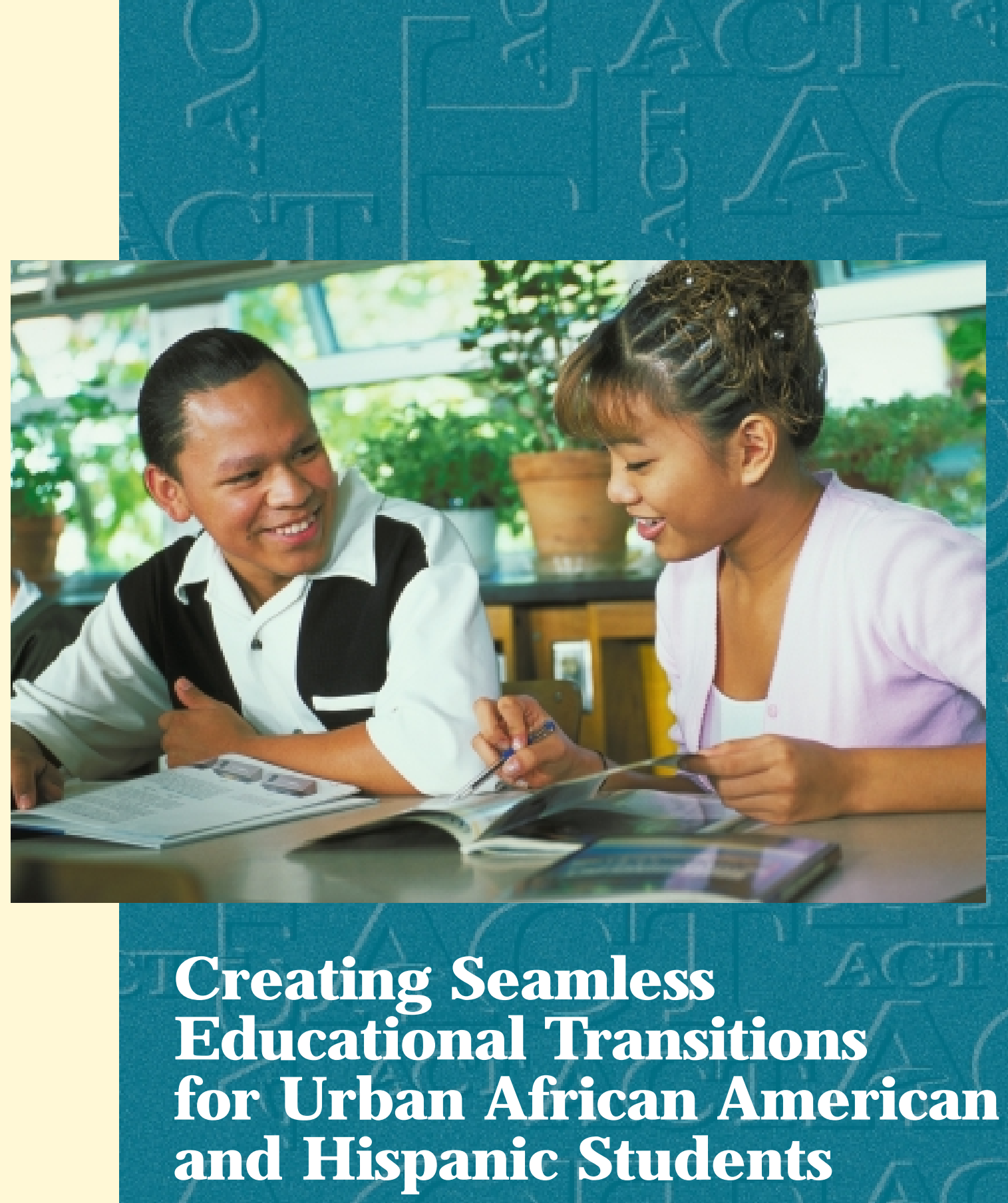

ACT POLICY REPORT

With THE COOPERATION OF THE

COUNCIL OF THE GREAT CITY SCHOOLS

RICHARD J. NOETH

GEORGE L. WIMBERLY 


\section{Creating Seamless EdUCATIONAL TRANSITIONS for Urban African American and Hispanic Students}

ACT Policy Report

With the cooperation of the Council of the Great C ity Schools

Richard J. N oeth

George L. Wimberly 


\section{Contents}

ACT Policy Research $\ldots \ldots \ldots \ldots \ldots \ldots \ldots \ldots \ldots \ldots$ iv

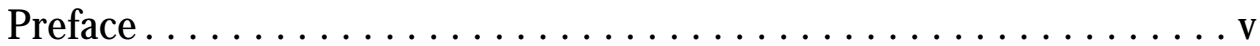

Executive Summary $\ldots \ldots \ldots \ldots \ldots \ldots \ldots \ldots \ldots \ldots \ldots$ vi

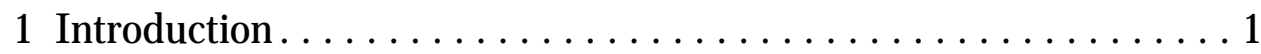

2 U rban African American and $\mathrm{H}$ ispanic Students ............. 5

3 The Present Study $\ldots \ldots \ldots \ldots \ldots \ldots \ldots \ldots \ldots \ldots \ldots \ldots$

4 Study Results: Parents and F riends $\ldots \ldots \ldots \ldots \ldots \ldots \ldots \ldots 12$

5 Study Results: High School Experiences . . . . . . . . . . . . . . . 16

6 Study Results: College Planning Resources . . . . . . . . . . . . 23

7 Study Results: College Costs and Financial Aid. ........... 28

8 Recommendations $\ldots \ldots \ldots \ldots \ldots \ldots \ldots \ldots \ldots \ldots \ldots \ldots \ldots \ldots \ldots$

Bibliography............................... 42 


\section{ACT Policy Research}

\section{Policy Research Advisory Panel}

\author{
John C. Barnhill \\ Director of Admissions \\ Florida State University \\ Julie D. Bell \\ Program Director of E ducation \\ National Conference \\ of State L egislatures \\ D on W. Brown \\ Commissioner of Higher Education \\ Texas Higher Education \\ Coordinating Board \\ Antonio R. Flores \\ President \\ $\mathrm{H}$ ispanic Association of \\ Colleges and Universities \\ Patricia M . M CD onough \\ Associate Professor \\ UCLA Graduate School of Education
}

Suellen K. Reed

Superintendent of Public Instruction Indiana Department of $E$ ducation

Carolynn Reid-Wallace

President

Fisk University

John H. Stevens

Executive Director

Texas Business and

Education Coalition

Gerald N. Tirozzi

Executive Director

National Association of

Secondary School Principals

M olly J. Tovar

Chief $O$ perating $O$ fficer

American Indian Graduate Center

\section{Office of Policy Research Staff}

\author{
Richard J. N oeth \\ Director \\ Susan C. L oomis \\ Senior Research Associate
}

\author{
George L. Wimberly \\ Research Associate \\ Peggy L. Weih \\ Administrative Assistant
}




\section{Preface}

The stated mission of the ACT Office of Policy Research is to inform policy makers and the general public on important issues in education by providing timely information that can directly enhance knowledge, dialogue, and decision making. The current ACT Policy Research Agenda focuses on four specific areas:

- D eveloping the Applicant Pool

- Increasing Diversity in College

- Remedial E ducation in College

- Retention in College

This study, Creating Seamless E ducational Transitions for Urban African American and Hispanic Students, was completed with the cooperation of the Council of the Great City Schools. It reflects ACT's interest in analyzing the critical issues affecting the preparation and diversity of the postsecondary applicant pool as well as in offering reasonable and concrete recommendations about ways to enhance the transition from high school to further learning.

This study and resulting policy report have greatly benefited from the contributions of many individuals and institutions. First and foremost, we are grateful to the students and staffs of the 23 high schools involved in this study. Without their generous cooperation, this study could not have taken place. In addition, administrators from each of the five urban districts-C hicago, L os Angeles, M iami-D ade County, M ilwaukee, and N ew Orleans- provided guidance in terms of school selection and contact information.

$M$ any individuals outside of $\mathrm{ACT}^{\mathrm{TM}}$ provided considerable help in formulating the study, reviewing study instrumentation, and/or reviewing draft report manuscripts. They include: William Boyd (Bolles School), D oris Clark-Parham (M urray State U niversity), Stephen D es) ardins (U niversity of I owa), Ray D ial (Waterloo, I owa, West High School), Sharon L ewis (Council of the Great City Schools), Barbara Schneider (U niversity of Chicago), and Chizu Shiono (Boston University). The focus group moderators were $\mathrm{N}$ icole $\mathrm{H}$ olland, Violin H ughes, Frederic H utchinson, Rosemary Polanco, and Ted Williams. The ACT Policy Research Advisory Panel provided both recommendations about the formulation of the study and reviews of draft manuscripts.

N umerous ACT staff members were involved in various stages of the study. Joe D ell Brasel, Jon E rickson, M ary H endrix, Carolyn Kostelecky, Chester L ucido, E rnest Valdez, Carla Vara, and Racquel Whitney provided assistance in district and school selection. D onald Carstensen, Patricia F arrant, Richard F erguson, Susan L oomis, Julie N oble, Wayne Patience, N ancy Petersen, Rose Rennekamp, Richard Sawyer, Cynthia Schmeiser, M ichael Valiga, L atricia Williams, and Ann York helped with instrument development and/or manuscript review. Kathleen Lynch, Jacqueline Snider, Peggy Weih, and Andrew Welch provided assistance in manuscript preparation and bibliography review.

We are grateful for the assistance and support of the aforementioned individuals but accept sole responsibility for any errors of omission or commission.

Richard J. N oeth

George L. Wimberly 


\section{E XecUtive Summary}

The major elements of a seamless P-16 system present both a cogent concept for education reform and a reasonable set of educational objectives. H owever, certain facets of this emerging system merit additional analysis and expanded development. Our study of five urban school districts focused on one specific and critical challenge- namely, whether the concepts and implementation elements of P-16 approaches currently in place adequately address the particular postsecondary planning and transition needs of urban African American and $\mathrm{H}$ ispanic students. This study examines the influences on postsecondary planning that these students have encountered and how such influences have helped them develop and implement their plans for postsecondary education.

The study concentrated on the postsecondary planning of African American and $\mathrm{H}$ ispanic seniors in five of the nation's largest urban school districts: Chicago, L os Angeles, M iami-D ade County, M ilwaukee, and N ew Orleans. In late spring 2001, just prior to graduation, 293 African American and $\mathrm{H}$ ispanic seniors from 23 high schools across the five districts completed a survey and participated in 90-minute focus groups about their college planning. Students who had taken the ACT Assessment ${ }^{\circledR}$ were selected by their counselors to represent a range of each school's African American and $\mathrm{H}$ ispanic senior population in terms of background and postsecondary education plans.

E ducational expectations of the study group were high. Students anticipated attending a two-year (16\%) or a four-year (80\%) college in fall 2001 . N early all expected to earn at least a bachelor's degree, and most expected to earn graduate or professional degrees. E ighty-four percent had been accepted to college, and the other $16 \%$ had either not yet applied or had not yet heard or been admitted to a college of their choice. $N$ inety percent viewed college as an important means to future job and career goals.

$M$ aternal influence was a significant factor for most students in the group. The majority indicated that their mother was very helpful $(63 \%)$ or somewhat helpful $(21 \%)$ in their college planning. For the $85 \%$ who had a father or male guardian present, $43 \%$ said he was very helpful and $19 \%$ indicated he was somewhat helpful. N early three-quarters said that friends and peers were very helpful or somewhat helpful in their college planning. Though many students

described how their parents encouraged and motivated them to attend college, they also indicated that their parents often were unaware of the many steps involved in postsecondary planning.

N early three-fourths said that their teachers and counselors were very helpful or somewhat helpful in their college planning. While activities might vary in terms of content, process, and timing, it seems that teachers and counselors in urban high schools take on a central role in helping students with postsecondary planning. Although the popular perception might be that principals have very little contact with students, especially in large urban high schools, a noteworthy finding of the study was that a quarter of the students felt that their principal was either very helpful or somewhat helpful in their college planning. Also, students often mentioned an "interested adult" in their school who influenced them, who identified them as having the 
potential to succeed in college and walked them through the postsecondary planning process.

N early all students reported that high school courses were very helpful (58\%) or somewhat helpful (34\%) in their college planning process-and a similar result emerged with regard to the influence of course grades. When asked about what advice to give younger students, they unanimously endorsed the need to start preparing for college earlier. M any of the students in our study reported that they had low grades during the ninth and tenth grades and, as a result, took less rigorous courses or repeated some courses. Almost $90 \%$ participated in extracurricular activities, and three-fourths said that this participation was helpful in their college planning.

M ore than two-thirds felt that information from the ACT Assessment was very to somewhat helpful in postsecondary planning. F or the students who had taken other college planning tests (75\%)-e.g., ACT's PLAN ${ }^{\circledR}$ - results were similar. Perhaps the comprehensive nature of these tests and their integrated emphases on academic achievement, college planning, and career exploration provided a breadth of tailored information that students could use for postsecondary transitions.

Of those students who were able to utilize college planning software (45\%), $61 \%$ found that such programs benefited them in their college planning. E ighty-three percent used specific college information (including that found via the Internet), and roughly three-fourths of these students found this information very helpful or somewhat helpful in their college planning. These combined findings indicate that a majority of urban college-bound African American and $\mathrm{H}$ ispanic students have access to computers and are using the Internet as part of their postsecondary planning. Less than half of the students $(42 \%)$ had participated in pre-college programs such as U pward Bound and Talent Search, but nearly $60 \%$ of those found these programs helpful. $M$ any students indicated, though, that they lacked college planning information, and some were unfamiliar with postsecondary opportunities. Others did not know the difference between two-year and four-year colleges, had haphazardly chosen a college, or planned to attend colleges they had never visited or knew very little about.

College costs and financial aid availability were major issues for students. Over half $(57 \%)$ indicated that costs were a major obstacle, and over a third $(36 \%)$ indicated that they were a minor obstacle in postsecondary planning. A significant majority (80\%) reported availability of financial aid very helpful $(59 \%)$ or somewhat helpful $(21 \%)$ in their planning. $M$ any students indicated that their families had limited economic resources to contribute to college expenses, but many expressed an intention to attend college even though they considered it basically unaffordable. $M$ any students also had problems adhering to deadlines-including registering for the ACT Assessment, completing the F ree Application for F ederal Student Aid (FAFSA), applying for scholarships, and completing college applications.

This study examined the particular postsecondary transitional needs and influences of urban African American and $\mathrm{H}$ ispanic high school seniors against the backdrop of a seamless P-16 education system. Based on a close look at 
five representative urban school districts and related research findings, we propose a number of educational policy recommendations that represent the core of a systematic and systemic approach that can directly support the postsecondary exploration and planning of urban African American and $\mathrm{H}$ ispanic students. The general and overarching recommendation is the following:

Districts should have and should implement an E ducational Transitions Strategic Plan that specifically includes and focuses on college exploration and postsecondary planning activities, programs, and outcomes that begin at least in the middle school and continue throughout high school.

Other specific recommendations include:

Schools should make concerted, systematic, and continuous effortsthrough an array of programs and information resources- to explain and reinforce the postsecondary planning process to parents.

C ounselors, teachers, principals, and other personnel should work to establish both formal and informal relationships with their students to assist them in various phases of the postsecondary planning process.

Schools should systematically use test information to help students plan their high school curriculum, identify areas for improvement, consider career options, and plan for postsecondary education.

Schools must continually reinforce with students and parents that financial aid is available to help pay college costs. 


\section{1 \\ INTRODUCTION}

\section{Seamless P-16 E ducation}

In his sixth annual State of American E ducation Address, N ew Challenges, $A$ New Resolve: M oving American E ducation Into the 21st Century (1999), former Secretary of E ducation Richard Riley described "seamless education" as the wave of the future. Secretary Riley's comments, given in Long Beach, California, reflect that city's substantial efforts to align the community's large $\mathrm{K}-12$ system with its multiple higher education institutions- through the L ong Beach E ducation Partnership - into one high quality, smoothly linked education system that would improve student achievement and teacher preparation (M cR obbie, 2001).

Van de Water and Rainwater (2001) at the E ducation Commission of the States define a seamless $\mathrm{P}-16$ system as one that represents an integrated concept of education that stretches from early childhood (where the "P" stands for pre-kindergarten or preschool) through a four-year college degree (grade 16). They describe some of the major goals of a seamless P-16 system as:

- Smoothing student transitions from one level of learning to the next

- Closing the achievement gap between white and minority students

- Strengthening relationships between families and schools

- Creating a wider range of learning experiences and opportunities for students in the final two years of high school

- I mproving college readiness and college success

Van de Water and Rainwater (2001) and others describe the impetus for this emerging $\mathrm{P}-16$ concept as a combination of numerous interdependent factors. These include the significant demographic shifts in the country's population; current and expected future workplace demands in terms of a skilled and learning-centered workforce; rapid advances in technology and technological applications throughout society; and the growing number of students who progress, largely unprepared, from one level of education to the next. All of these factors require substantial changes in how educational services are conceptualized, aligned, and delivered.

Van de Water and Rainwater (2001) define the strengths of a seamless P-16 system as inclusiveness (i.e., creating an environment that expects success from everyone), the alignment of efforts at all levels to facilitate transitions, support for standards and assessments, efficiency and effectiveness, and a reduction of the need for remediation. K leiman (2001) also characterizes a major aspect of $\mathrm{P}-16$ in terms of postsecondary preparedness. $\mathrm{He}$ describes this as the pooling of resources of the postsecondary and K-12 systems to pursue the common goal of turning out better-prepared, better-educated students. He sees it as an opportunity to open up the dialogue between the two systems, to work together to improve teacher training, strengthen 
curricula, and provide students with the information and support they need to succeed. Van de Water and Rainwater (2001) highlight the need to improve college readiness and success by recommending universal postsecondary education, which will require dropping the general track from secondary schools and providing all high school students with the skills required to succeed in college.

Pipho (2001) includes the need for a parent information plan that communicates the P-16 system's expectations of learners through postsecondary training. $\mathrm{H}$ e recognizes that parents need an ongoing information system that clarifies the expectations and options their students will encounter as they move through the system. H e uses a grade 7-8 example that focuses on the importance of mathematics and science skills, particularly the completion of algebra. At this point, he recommends that parents and students should be given specific information about academic expectations in high school and college. F urther, he suggests that postsecondary institutions should conduct special mentoring programs, academic summer camps, and other events that make thinking about high school and college an integral part of students' daily education fare.

\section{The Need to Expand Seamless P-16 I mplementation}

The major elements of a seamless P-16 system present a cogent concept for education reform and a reasonable set of manageable and measurable objectives. As a concept that is gaining widespread recognition, certain facets of the P-16 system merit further analysis and development. This study addresses one such challenge: namely, within the transitional emphasis of a seamless $\mathrm{P}-16$ system, the necessary concepts and implementation elements currently do not seem to be in place to adequately address the particular postsecondary planning and transition needs of urban African American and $\mathrm{H}$ ispanic students. These needs- which appear to go beyond the important aspects of curriculum, teacher training, assessment, and standards- require the addition of focused leadership, communication, community involvement, integrated planning, and accountability toward the goals of improving access to postsecondary education and facilitating the transition to postsecondary training.

The postsecondary planning process is a combination of behaviors and actions taken throughout P-16 that enables a student to (1) successfully transition from high school to postsecondary education and (2) successfully complete desired postsecondary training. It includes the behaviors a student engages in throughout P-16 that contribute to developing college aspirations, acquiring skills and knowledge to become a successful applicant, evaluating information about postsecondary institutions and financial support, matriculating as a college student, and successfully completing postsecondary education. These actions and planning activities can include, but are not limited to:

- Considering postsecondary education

D eciding to attend college

- Selecting high school courses to prepare for postsecondary training

- M aintaining good grades in high school courses

- Obtaining information about colleges and academic programs 
- Obtaining information about financial aid opportunities

- Preparing for and taking college admissions tests

- Exploring college major and career interests

- Visiting college campuses

- Completing college admission applications

- Applying for financial aid and scholarships

- Selecting a college to attend

The process of postsecondary planning can begin with the aspiration (often unstated) to seriously consider going to college. $M$ any students have always had high educational aspirations (Akerhielm, Berger, H ooker, \& Wise, 1998; F reeman, 1999; K ao \& Tienda, 1998; O 'Connor, 1997). Their parents, teachers, and others around them have worked to ensure that they would go to college. This is particularly true for students whose parents have attended college and can provide a head start in terms of course planning and obtaining college-related information (M CD onough, 1997).

$M$ any students also decide to attend college at specific points in their schooling. Sometimes they will participate in pre-college programs such as Upward Bound or GEAR UP to expose them to postsecondary options. Some will decide late in high school that college is the best option for them, while still others will not consider postsecondary training for many years beyond high school. F or other students, a job experience or thoughts about a particular career may spark an interest in college (C sikszentmihalyi \& Schneider, 2000). First-generation college-bound students often do not receive timely college planning information, might not take the necessary courses, and might struggle with cultural conflicts between their new college-oriented world and the world of their friends, families, and communities (M CD onough, 1997).

$M$ any factors influence students as they consider, develop, and pursue postsecondary plans. Influences often include individuals, institutions, programs, activities, and experiences which, either directly or indirectly, facilitate college planning. These influences may provide students with information about school and college success, expand awareness of postsecondary and career options, increase educational expectations, identify educational opportunities, and help students make the transition to college. $M$ any sources of information and support are available for high school students. M any high schools devote their curricula to college preparatory courses to ensure that graduates are ready to meet the demands of higher education. As students progress through elementary, middle, and high school, they learn from their schools, teachers, parents, and society about the importance of a college education and how to plan for it. As early as eighth grade, most students expect to attend college and have a professional career. Such educational expectations are consistent across race and social class (F reeman, 1999; K ao \& Tienda, 1998; M acL eod, 1995; W imberly, 2000).

$M$ inority students are less likely to attend college and earn a degree than white students. In particular, though African American and $\mathrm{H}$ ispanic students attending urban schools may have the desire and expectation, they may not have the skills, knowledge, and information they need to enter and complete a postsecondary program. $\mathrm{M}$ any do not understand the preparation required to 
meet their educational and career aspirations. They do not have the informational resources, personal support networks, continual checkpoints, or structured programs to make college exploration and planning a theme throughout their daily lives. F or this to happen, students need their schools, parents, and others to help them plan for college and their future careers (Schneider \& Stevenson, 1999).

\section{Purpose}

This study examines the influences on college planning that urban African American and $\mathrm{H}$ ispanic students encounter and how these influences help them develop and implement their plans for postsecondary education. Within the concept of a seamless P-16 education system, findings from this study combined with results of other studies can help shape education and social policies and practices aimed at improving the educational achievement, preparation, and transitions of urban African American and $\mathrm{H}$ ispanic students-as well as increasing the number of these students entering postsecondary education.

Our conclusions and recommendations focus primarily on the middle and high school links of the P-16 education chain. The conclusions suggest expansions to the implementation of the seamless P-16 concept, as the current literature does not adequately address how postsecondary planning should happen, how and when all necessary participants should be involved, and how the particular transitional needs of certain school populations would best be met. This research can lead to systematic and systemic $\mathrm{P}-16$ policies and programs that will better equip students, parents, schools, colleges, and communities to meet the postsecondary planning needs of urban African American and $\mathrm{H}$ ispanic students. 


\section{2}

\section{Urban African American and Hispanic Students}

The shift from an industrial to a service, information, and technology-based economy has dramatically increased the importance of advanced skills and credentials. Given the rapid changes in the U.S. economy, growing competition across the global market, and increasing labor force skill requirements, postsecondary training has become a necessary expectation both as a societal need and as an individual aspiration. What was once a privilege and a right for the chosen few has now become a necessary expectation for America and for nearly all Americans-regardless of gender, racial or ethnic background, or geographic location. Clearly, the future strength of the American workforce and economy will depend to a large degree on the successful transitions of urban African American and $\mathrm{H}$ ispanic students across the P-16 system.

\section{E ducational Trends}

African American and $\mathrm{H}$ ispanic students have experienced continued increases in public school enrollment, high school graduation rates, college entrance, and degrees earned. African American public school student enrollment grew from $15 \%$ to $17 \%$ between 1972 and 1999. H ispanic student enrollment

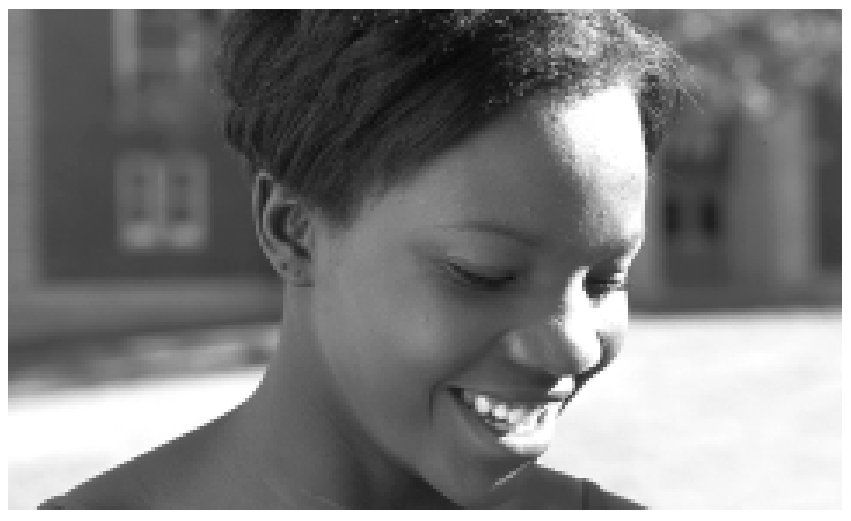
increased from 6\% in 1972 to 16\% of the public school population in 1999 (U.S. D epartment of E ducation, 2001a). Part of this enrollment increase is due to the upsurge in $\mathrm{H}$ ispanic immigration to the U nited States, with $\mathrm{H}$ ispanics fast becoming the largest minority group in America. It is projected that in the next 30 years minority people will make up over one-third of the U.S. population, and in several states no ethnic group will constitute a majority.

Today, attainment of a high school diploma has become common among young adults. In 1972, 78\% of all 25- to 29 -year-olds had earned a high school diploma. $\mathrm{H}$ igh school graduation rates varied considerably by race, with $82 \%$ of whites, $59 \%$ of African Americans, and $48 \%$ of $\mathrm{H}$ ispanics finishing high school. H owever, by the 1990s the high school graduation gap between whites and African Americans had narrowed. In 2000, over 85\% of African Americans and nearly all white 25- to 29-year-olds had completed high school. H owever, $\mathrm{H}$ ispanic high school graduation rates continued to lag behind, with only $63 \%$ finishing high school (U.S. D epartment of E ducation, 2001a). College enrollment among African Americans and $\mathrm{H}$ ispanics has also increased since the 1970s. In 1975 African Americans made up 10\% of the college population and $\mathrm{H}$ ispanics 4\%; by 1999 the percentages of college enrollment had risen to $13 \%$ and $9 \%$, respectively, for African Americans and $\mathrm{H}$ ispanics.

These increases in graduation rates and college enrollment come at a time when a high school diploma has minimal value in the labor market. 
U nemployment rates are the highest among African American and $\mathrm{H}$ ispanics with a high school diploma or less, whereas racial differences in unemployment are insignificant among people holding college degrees (U.S. D epartment of E ducation, 2001b). Among those age 25-34 with a bachelor's degree, males earn 58\% more and females 92\% more than those with only a high school diploma (U.S. D epartment of E ducation, 2001a).

College graduation rates have also increased for African Americans and $\mathrm{H}$ ispanics. In 1977, African Americans earned $7 \%$ and $\mathrm{H}$ ispanics earned $2 \%$ of bachelor's degrees in the U.S. By 1998 African Americans and H ispanics earned, respectively, $9 \%$ and $6 \%$ of bachelor's degrees. H owever, African American and $\mathrm{H}$ ispanic students who enroll in college are less likely than whites to earn a degree. In 1995, over half of white students had earned a bachelor's degree within five years of enrollment, compared to less than onethird of African American and H ispanic students (U.S. D epartment of E ducation, 2001b).

African American and $\mathrm{H}$ ispanic students tend to be concentrated in urban schools, which often have a higher poverty rate than rural or suburban schools, as K ozol (1991) poignantly documents in his book Savage I nequalities: Children in America's Schools. U rban students' high school graduation and postsecondary degree attainment rates lag behind their rural and suburban peers (Lippman, Burns, \& M cArthur, 1996). M uch of their low educational attainment is attributed to the poverty concentration in these school districts. Urban schools disproportionately face challenges that include high dropout rates, low student achievement, funding problems, and frequent changes in school leadership. These and other factors make it more difficult for urban schools to produce graduates who are well prepared for postsecondary training and for success beyond high school.

\section{The I mpact of Policy Changes}

The increase in African American and $\mathrm{H}$ ispanic educational participation can be attributed in large measure to changes in social and educational policies designed to increase minority access to higher education and the labor market. Since the 1954 Brown v. Board of Education decision, which abolished legal racial segregation in the nation's schools, a number of social and educational policies have been aimed at improving educational opportunities for minority students.

Beginning in the early 1970s, the federal government began funding Pell Grants to provide tuition assistance for low-income students to attend college as part of the War on Poverty Program. Civil rights legislation led to affirmative action initiatives designed to increase higher education and labor market participation among minorities and women. Federally-funded Title I Programs were geared toward help in reading and math, U pward B ound Programs focused on increasing college going, and many local partnerships among school districts, colleges, and private businesses were aimed at increasing college going among minority and low-income students.

Postsecondary institutions eventually began to recognize the educational and social value of having racially and economically diverse student populations. $M$ any elite colleges and universities sought to advance their students' 
educational experiences by actively recruiting minority students and providing scholarships to low-income students (B owen \& Bok, 1998). These combined efforts helped lead to a near tripling of the African American college population between 1966 and the late 1970s.

Changes in the college student population came as many institutions experienced rising costs. In the late 1970s college tuition costs grew at three times the rate of inflation. F ederal and state governments cut funding to colleges, forcing them to raise tuition, and financial aid shifted from grants to student loans (College B oard, 2000; King, 1996). As college costs increased into the 1980s, African American college attendance stabilized at just over $9 \%$ of the college population (U.S. D epartment of E ducation, 2001b).

D uring the '70s and ' 80 s, colleges employed affirmative action policies and programs to admit minority students and thus add racial and economic diversity to their campuses. I nitial affirmative action policies gave preferential status to minorities and women. Schools sometimes used quota systems to obtain a specific percentage of students from underrepresented groups, thereby admitting many minority students who might not have been admitted under traditional policies.

Affirmative action programs and policies have come under numerous legal challenges. In 1978, the Supreme Court eliminated quota-based admissions programs with the Bakke decision but allowed institutions to consider race in college admissions and to continue to actively seek a diverse student population. Although many of the War on Poverty and civil rights programs were dismantled or reduced in the 1980s, colleges continued recruitment efforts to maintain minority access to higher education.

In 1995 the people of California, through Proposition 209, voted to exclude consideration of race and ethnicity for admission to the $U$ niversity of California System (Bowen \& B ok, 1998). Affirmative action policies were again curtailed in 1996 when the F ifth Circuit Court of Appeal's decision in the Hopwood v. Texas case banned racial preference in college admission. The Court ruled that the U niversity of Texas Law School had taken the necessary steps to increase its minority student population and that it was unlawful to give one race preferential treatment over another for the sake of diversity. Following the Hopwood decision, Texas universities experienced a decline in minority applicants, as they could no longer recruit minority candidates and offer them race-based scholarships (Chapa \& L azaro, 1998).

N ow, several generations removed from the introduction of policies to increase opportunities for minority students, postsecondary education is more accessible than in the past. Yet, although more accessible, the transition from high school to college still involves many steps. These steps require a considerable amount of information, assistance, action, and support. U rban African American and $\mathrm{H}$ ispanic students face considerable challenges in this regard. They often must strive harder to find and then use the available information resources in their schools, families, and communities and overcome more obstacles in this process than their suburban and rural peers. F or them, developing exploration, planning, and decision-making behaviors to complete high school, plan for college, and successfully make the transition to higher education is often a difficult road and often the one less traveled. 


\section{The Present Study}

This study focuses on the postsecondary planning of African American and $\mathrm{H}$ ispanic high school seniors in five of the nation's largest urban public school districts: Chicago, L os Angeles, M iami-D ade County, M ilwaukee, and N ew Orleans. These districts were selected based on their membership in the Council of the Great City Schools, urbanicity, size of minority student population, and number of seniors taking the ACT Assessment. L os Angeles, Chicago, and M iami-D ade County public schools are three of the country's largest school districts. E ach has a large minority student population, and $60 \%$ or more of its students receive free or reduced-cost lunch. They face challenges similar to those of many urban districts: high poverty concentration, low graduation rates, inadequate funding, and overcrowded schools.

ACT field staff, the Council of the G reat City Schools staff, and local school administrators helped identify four or five schools in each district to participate in the study. Participating schools had populations ranging from 850 to 5,000 students. ACT collected data

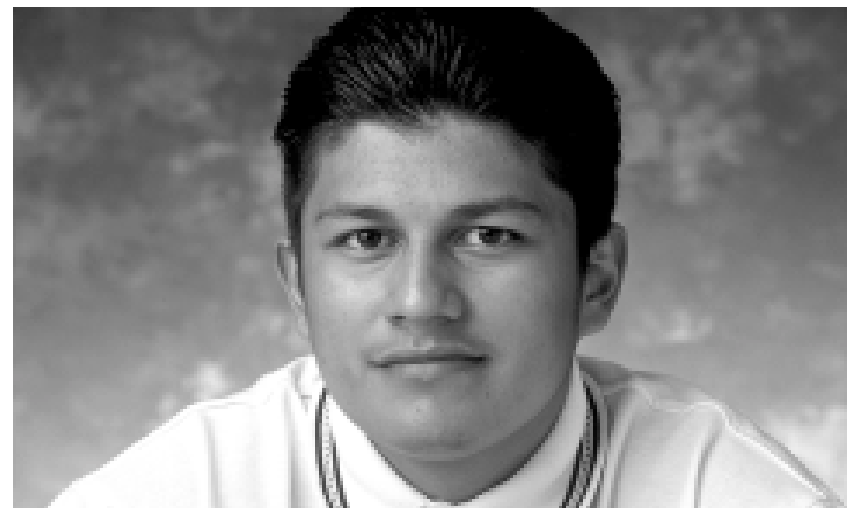
from students in 23 public high schools in the five school districts.

In late spring 2001, just prior to graduation, African American and $\mathrm{H}$ ispanic high school seniors from the 23 urban high schools completed a survey on college planning and then participated in 90-minute focus group discussions with trained facilitators. Counselors at each high school selected a range of 10-20 African American and/or $\mathrm{H}$ ispanic seniors who had taken the ACT Assessment to participate in this study. The criteria for participation were that students represented a range of the school's African American or $\mathrm{H}$ ispanic senior population in terms of backgrounds and plans and that they had taken the ACT Assessment. Participants ( $N=293$ ) had a diverse set of backgrounds, school experiences, and academic achievements. F igure 1 shows that $65 \%$ of the students surveyed were African American, 30\% were $\mathrm{H}$ ispanic, and 5\% belonged to other racial groups. Twenty percent of the fathers and $26 \%$ of the mothers earned a bachelor's or higher degree (Table 1). Roughly one-third of the students reported that their parents had a high school diploma or less. 
Figure 1:

Students' Racial

Breakdown

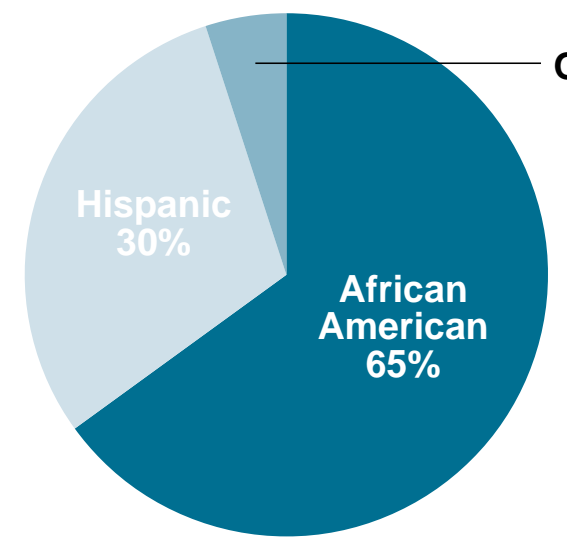

Table 1

H ighest E ducational Attainment of Parents (in percent)

Education Level

F ather/Male

Mother/F emale

Guardian

Guardian

$\begin{array}{lcc}\text { Some high school } & 14 & 12 \\ \text { H igh school diploma or GE D } & 23 & 21 \\ \text { Some college, no degree } & 12 & 17 \\ \text { Vocational/technical degree } & 6 & 6 \\ \text { Associate degree } & 5 & 6 \\ \text { Bachelor's degree } & 11 & 13 \\ \text { M aster's degree } & 6 & 9 \\ \text { D octorate/professional degree } & 3 & 4 \\ \text { D on't know } & 20 & 12\end{array}$

Students were divided into two groups per school to complete the College Planning Survey, which included questions about potential influences of college planning. D uring subsequent 90 -minute focus-group sessions with trained facilitators, students were given the opportunity to elaborate on factors that influenced their postsecondary planning, discuss their own college and career plans, and make suggestions regarding information that would help younger students to explore and plan for college.

An earlier version of the College Planning Survey had been used with collegebound seniors in the state of Washington (N oeth, E ngen, \& N oeth, 1984). The current version was revised to reflect factors and wording more appropriate for a contemporary urban environment and then was reviewed by a panel consisting of a college admissions officer, a college counselor, six educational researchers, and a school administrator. The survey was again field tested with a group of urban high school seniors. ACT staff and trained facilitators then administered the survey to students during the final weeks of their senior year of high school. This is a time when one would expect that the college planning process has culminated, that students have made their postsecondary decisions and will soon begin the college transition. 


\section{Plans and Expectations}

Students were asked about their educational expectations, long-term educational plans, and reasons for planning to attend college. The findings indicate that nearly all the students anticipated attending a two-year or a fouryear college in fall 2001. E ighty percent planned to attend a four-year college or university and $16 \%$ expected to attend a community college or vocationaltechnical school.

This study was conducted in late spring of the students' senior year. At this point, $84 \%$ of these high school seniors indicated that they had been accepted to a college (two- or four-year) for the following fall. Of the remaining $16 \%$, $7 \%$ had not yet applied to college and $9 \%$ had not yet heard from institutions regarding their admission or had not been admitted to a college of their choice.

The African American and $\mathrm{H}$ ispanic urban students in this study had high educational expectations. F igure 2 shows that nearly all respondents expected to earn at least a bachelor's degree and most expected to earn a graduate or professional degree (MA, M BA, PhD , MD , JD). As these students were preparing for their upcoming high school graduation, not only did they not see high school as the end of their formal training, most did not view undergraduate training as the last stop on their formal education journey.

Figure 2:

Students'

Educational

Expectations

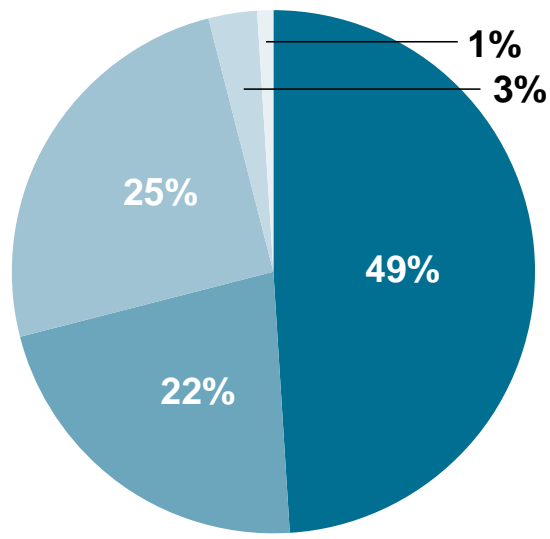

Vocational/technical program (less than 2 years)

Two-year college degree

Bachelor's degree

1 or 2 years of graduate study (MA, MBA, etc.)

Professional level degree (PhD, MD, JD, etc.) 
The overwhelming majority of students (90\%) in this study linked college attendance to their future job and career goals. Figure 3 shows that $71 \%$ of students indicated that college as a means to a job was a very important aspect of their college planning ( $19 \%$ indicated it as somewhat important). These findings clearly suggest that these urban African American and $\mathrm{H}$ ispanic college-bound seniors were directly focused on the career outcomes of their postsecondary education. As reported in the focus groups, future prosperity seemed to motivate many students to pursue college, and many noted that they did not want to hold low-wage jobs like their parents. Particularly among those students from $\mathrm{H}$ ispanic immigrant families, many indicated that their families came to the U nited States for better educational opportunities. These results are similar to other studies that report that many minority students desire to have more education and higher-status careers than their parents (F reeman, 1999; Ginorio \& H uston, 2001).

Figure 3:

College as

a M eans

to a Job

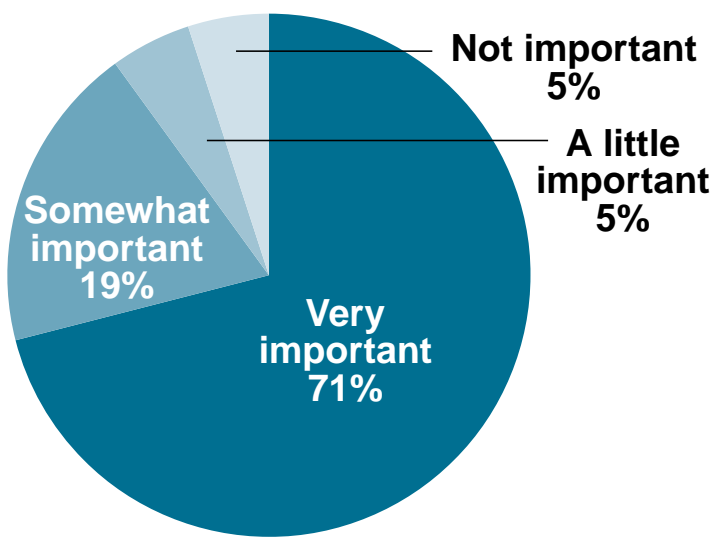




\section{4 \\ Study Results: Parents and Friends}

\section{Parents}

Studies show that children's academic success depends greatly on parents' involvement in their education (E pstein, Coates, Salinas, Sanders, $\&$ Simon, 1997; M uller \& Kerbow, 1993). When the parents are well educated, parental involvement can increase students' school success, facilitate college planning, and increase the likelihood that their children will attend college (College Board, 1999). Parents play influential roles in postsecondary planning by saving money for college, helping students select courses, facilitating college visits, and providing their children with information about college. Parents' role in college planning can also involve instilling strong educational values and the desire to go to college.

$\mathrm{H}$ igher education is important for all Americans, but it is especially important to African American and $\mathrm{H}$ ispanic parents, who are significantly more likely to emphasize it than white parents (I mmerwahr, 2000). African American and $\mathrm{H}$ ispanic parents often teach their children that a college education will help them avoid unemployment and the general problems associated with poverty. African American students often want to go to college to do better than their parents, as well as to overcome economic and social hardships (F reeman, 1999; I nstitute for $\mathrm{H}$ igher $\mathrm{E}$ ducation Policy, 2001). These students often perceive a college education as essential to obtaining a good job, developing a promising career, and becoming successful in life.

$\mathrm{H}$ ispanic parents also expect that a college education will expand their children's career and economic opportunities. $\mathrm{H}$ ispanic immigrants, in particular, often come to the U nited States to gain employment and provide educational opportunities for their families (Gándara, 2001; Ginorio \& H uston, 2001). Some H ispanic cultural differences may inadvertently conflict with traditional school models. F or example, although valuing education for their children, $\mathrm{H}$ ispanic parents value family above all. F ormer Secretary of E ducation Riley, in acknowledging this, has affirmed that $\mathrm{H}$ ispanic parents must be supported in guiding their children to take challenging courses and in providing them the support to stay in school and go on to college (2000).

M otherhood is particularly important, and females may not always be encouraged to pursue college and a career outside the home (Kelly, 1995). $\mathrm{M}$ any $\mathrm{H}$ ispanic students who feel obligated to remain close to the family home forgo college for the family's needs. School counselors report that it often can be difficult to encourage $\mathrm{H}$ ispanic students with these values to pursue college degrees (Ginorio \& H uston, 2001).

Parents' education level and income are strong predictors of children's educational attainment (College Board, 1999; Sewell, H aller, \& Portes, 1969; Sewell $\&$ H auser, 1980). B ecause of their knowledge and experience, parents with college degrees may be better able to provide college planning 
information and resources than parents with less education. Because collegeeducated parents have experienced college themselves, they help keep their children on schedule for taking appropriate courses, preparing for college admissions tests, applying for scholarships and financial aid, visiting college campuses, and submitting college applications.

$M$ any parents, particularly those who have not attended college, may not have the necessary tools to assist their children with college planning (Institute for $\mathrm{H}$ igher E ducation Policy, 1998). These parents may have high educational expectations for their children but lack information and knowledge about what their students need for college readiness, planning, and success. Parents who have not attended college are less likely to discuss college with their children (H orn \& N uñez, 2000). This is true even among high-achieving students. These parents are also less likely to obtain information about specific colleges, pursue educational opportunities for their children, or complete financial aid forms. Poor families and those from underrepresented groups are much less likely to have sufficient familiarity with the social and educational systems, and to have access to information and resource networks (G ándara, 2001). Parents who lack college planning information must rely primarily on the school (and to some extent on the community) to provide the resources necessary for college exploration, planning, and decision making.

\section{Peer Group/Friends}

Peer groups and friends often play a significant role in students' school success and college planning. Studies have shown how peer groups can have positive effects on students' college planning processes and educational experiences (H ossler, Schmit, \& Vesper, 1999; H rabowski, M aton, \& G reif, 1998). Peer groups can support school success when students share a commitment to educational values. Students often participate in pre-college programs with their peers where they jointly gather college planning information. Peer groups may study for tests together, help each other write papers, share college experiences, and share information that promotes education (Kahne, 1999).

H owever, peer groups and friends can also have a negative impact. Some studies reveal that when a student's peer group is resistant to school performance, academic achievement and educational attainment are low ( $\mathrm{M}$ acL eod, 1995). M any African American and $\mathrm{H}$ ispanic adolescents may belong to peer groups that do

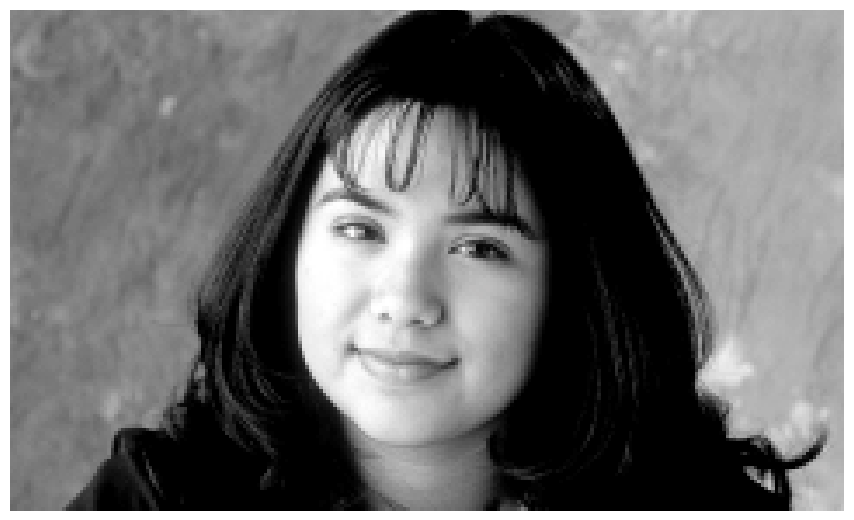
not encourage or value education. African American males may be forced to choose between "white values" such as individualism, competitiveness, power, and dominance, and a peer group that discourages education (Corbin \& Pruitt, 1999; O 'Connor, 1999). Such negative school experiences may result in low educational expectations and attainment among African American males.

Overall, however, analysis of national data reveals that African American and $\mathrm{H}$ ispanic students desire academic success just as much as white students 
(Cook \& L udwig, 1998; Ginorio \& H uston, 2001; K elly, 1995). The friend and peer influences are cited often by M CD onough (1997) who discusses multiple students' career planning processes. One review (Wells \& C rain, 1994) has implied indirectly that as peer groups change, attending a school with other racial/ethnic groups provided African American students with access to information and sponsorship networks required for increased educational attainment.

\section{Study F indings}

The influence of family and friends on postsecondary planning is reported in F igure 4. Virtually all students reported their mother or female guardian as an influence factor. The vast majority of students $(84 \%)$ indicated that their mother was very helpful (63\%) or somewhat helpful $(21 \%)$ in their college planning. For the $85 \%$ who had a father or male guardian present, $43 \%$ said their father was very helpful and 19\% indicated somewhat helpful. Over onethird of students (37\%) indicated that their friends/peers were very helpful; another $37 \%$ said that they were somewhat helpful with college planning.

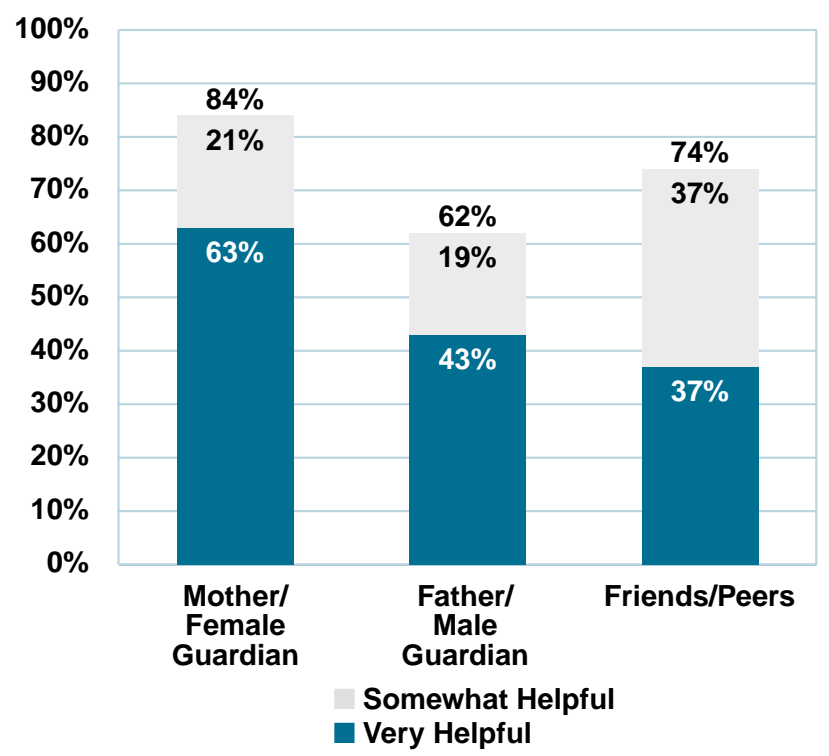

Figure 4: Influence of Parents and Friends on Postsecondary Planning

The findings clearly indicate that most students perceived their mother as being a strong influence on their college planning process. $M$ ore students reported their mother as being more helpful in their college planning decisions than any other person or college planning factor. This is consistent with previous research that found students rely greatly on their mothers for high school course selection, college plans, and ultimate college decisions (H esel, 1998; H orn \& N uñez, 2000) and are strongly influenced by their mothers' expectations for them (F reeman, 1999; H ill, 1999; Painter \& L evine, 2000). F athers also have a strong influence on students' college plans, but not to the same extent as mothers. The strong mother influence in general has partly been attributed to the higher percentage of mother-only families, particularly among African Americans. 
$M$ any students in the focus groups described how their parents had encouraged and motivated them to attend college. Parents tended to be these students' greatest cheerleaders, but it is clear that their parents may not have had the necessary tools and resources to help them with postsecondary planning. $M$ any students indicated that their parents wanted them to attend college, but were unaware of the many steps in college planning, such as taking college admissions tests, visiting campuses, and applying for financial aid.

Students may experience the college planning process with their friends and classmates through a variety of activities. Consistent with previous research, this study finds that friends and classmates play an integral role in students' college planning and academic success. Some suggest that peers may be a significant source of college planning information among African American and $\mathrm{H}$ ispanic students because their parents are limited in the amount and type of college planning information they can provide (H ossler et al., 1999; Wimberly, 2000). 


\section{Study Results: High School Experiences}

\section{School Staff}

$\mathrm{H}$ igh schools are an essential source of college planning information for students and parents. They often provide resources about the college planning process and different colleges. They provide staff to guide students through this complex process, including assistance with course selection, college applications, college admission test preparation, and financial aid applications. $M$ any high schools link students with colleges, local businesses, and other opportunities to help them develop social, college planning, and academic skills.

$M$ any minority students and students whose parents did not attend college rely primarily on their schools for college planning help. They often use teachers, counselors, and other school personnel to gain access to college and career planning information (E pps, 1995; Stanton-Salazar, 1997), although some have only used school personnel when completing

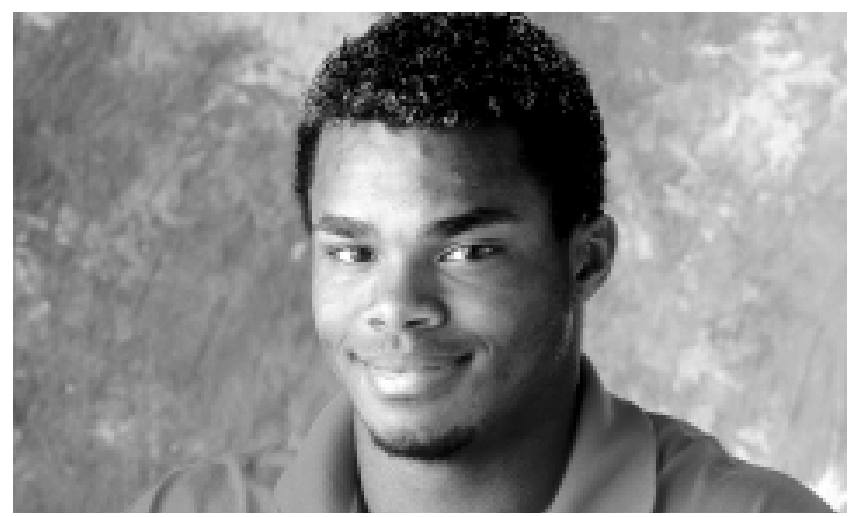
financial aid forms (H orn \& N uñez, 2000). By virtue of their knowledge and experience, staff can provide information on- as well as access to-educational opportunities, which can enhance students' chances both for college entrance and career success.

Although their primary role is to instruct students in specific academic areas, teachers can be a source of support and influence (Gándara, Gutiérrez, \& O'H ara, 2001). Along with other school staff, teachers can be a source of encouragement and information about courses students should take in preparation for college as well as for various elements of the college planning process. Teachers often write letters of recommendation for students applying to college and for scholarships. Such letters can often provide significant insight and information about the student that is not reflected in grades and test scores (M CD onough, 1997).

Counselors can and should play a significant role in college planning (ACT, 1999; American School Counselor Association, 1997). They can help students identify educational opportunities and channel information to students and their parents about various colleges, financial aid, and other information that students need to be admitted to college. In most schools, the counselor is the key person to assist students in the postsecondary planning process. Counselors ensure that students meet the academic course requirements for graduation and take the appropriate courses required to prepare them for college. They may help students decide what type of postsecondary option best fits their goals, preparation levels, and current needs. M any school districts designate a counselor who focuses primarily on college planning 
activities (e.g., "the college counselor"). These counselors arrange for college admissions officer visits, ensure that students take college admissions tests, help them apply for financial aid, help them complete college applications, and advise them as they make college choices.

Counselors often are not involved in college planning until students' senior year of high school. Unfortunately, this is too late to suggest appropriate high school courses and to encourage students to become involved in activities related to their interests, maintain good grades, and apply to specific colleges (H orn \& N uñez, 2000). This problem has been further exacerbated in recent years as the role of the counselor has shifted from offering career and educational guidance to dealing with social problems such as drug abuse, violence, and teen pregnancy (M cD onough, Korn, \& Yamasaki, 1997). This shift in counselor responsibilities, along with reductions in school counseling staffs, has resulted in many students receiving inadequate or little college counseling.

Counselors who face diminished resources and increased responsibilities may tend to encourage and guide only higher-achieving students to plan for college, leaving lower-achieving students to seek college information on their own or flounder. Particularly in urban high schools, counselors may have to address substantial personal and social problems affecting students and the need to ensure that students graduate from high school. Although high school graduation has become relatively common, urban schools continue to have low graduation rates, high dropout rates, and other social problems that can disrupt students' progress through high school. D ealing with these issues may make it difficult for counselors to focus their efforts on college planning.

\section{High School Courses}

Colleges and universities continue to stress the importance of coursework and grades in college admissions (B reland et al., 1995). The importance of high school courses has increased as postsecondary institutions have continually refined their requirements for admission. $\mathrm{H}$ igh schools have increased the number of college preparatory courses students are required to take since the report $\mathrm{A}$ Nation at Risk ( $\mathrm{N}$ ational Commission on Excellence in $\mathrm{E}$ ducation, 1983), which outlined the shortcomings of the American educational system.

A rigorous high school curriculum is often the strongest predictor of entering college and earning a degree (Adelman, 1999). M any studies have found, for example, that taking high-level math courses increases college going among minority and first generation college students (Adelman, 1999; E ducation Commission of the States, 2001; H orn \& N uñez, 2000). F urther, students who take algebra in eighth grade are very likely to apply to a four-year college, controlling for other high school course taking (Atanda, 1999). A similar pattern was found among students who take a foreign language in eighth grade. This suggests that for students who plan to go to college, demanding coursework as early as eighth grade will increase their chances for college success. As course requirements become standard, it is important to ensure that the corresponding course content prepares students for the rigors of college (N ational Commission on the H igh School Senior Year, 2001). $M$ any education reformists have supported advanced courses in all high 
schools and have encouraged local colleges to offer college-level courses to high school students. The U tah State L egislature recently proposed that all students who enter college should have earned some college credit before matriculation (E ducation Commission of the States, 2001).

M ost students expect to attend college as early as middle school (Cabrera \& La N asa, 2000). Yet many urban schools typically face low student

achievement in reading and math. Students may begin high school unprepared for a college preparatory or core curriculum, making it difficult for teachers, counselors, and other school personnel to adequately prepare these students for college. Programs such as GE AR UP provide federal funds for schools to prepare low-income middle school students for high school and college preparation through multiple school reform efforts. School districts, colleges, community organizations, and businesses often form partnerships to provide teachers with enhanced professional development opportunities to ensure they have the necessary tools and strategies to teach middle and high school subjects effectively.

Students at higher academic levels are more likely to obtain information about postsecondary opportunities than students at lower academic levels. M uch of the student stratification within academic courses reflects the social and economic stratification of society (L ucas, 1999). Schools using tracking systems or other methods that ultimately place low-income and marginal students in lower-level academic courses are not adequately preparing them to plan for postsecondary education, succeed in college, and prepare for lifelong learning.

Students who take a college preparatory or core curriculum perform better on college admissions tests than do students who have taken a less rigorous curriculum. F or example, students who take the core courses perform better on the ACT Assessment than those who have not taken these courses. (The core courses consist of four years of E nglish and three years of mathematics, science, and social studies.) This finding is consistent across urban schools in that urban students who have taken a core curriculum perform better on the ACT Assessment than students who have taken less than core (Council of the Great City Schools \& ACT, 2001).

\section{Extracurricular Activities}

Participation in extracurricular activities helps students develop their interests and skills, build their involvement with their schools, and establish relationships with school personnel, as well as gather college-related information (Youniss \& Yates, 1997). They can learn citizenship and collaboration skills and become stronger students through participation in extracurricular activities. These activities allow students and school personnel to interact informally, developing relationships that can influence college plans. Through connections with mentors, coaches, and club moderators, students can foster relationships that help them obtain college information, informally discuss the college exploration and planning process, and provide a resource for recommendation letters as they apply for college admission (M atthay \& N ieuwenhuis, 1995). 
Students who participate in extracurricular activities tend to have higher grade point averages, better attendance records, lower dropout rates, and fewer discipline problems than the general student population (Brown \& E vans, 2002). They learn time management skills to balance their schoolwork and their activities, which can help with college planning as they learn to plan ahead and make choices. M ost school districts require students to maintain a certain grade point average to participate in extracurricular activities, which motivates them to work hard in school so they can continue with activities they enjoy.

Conversely, research suggests that students who spend no time in extracurricular activities are more likely to drop out of high school, use drugs, become teen parents, smoke cigarettes, and use alcohol than students who participate in activities (U.S. D epartment of H ealth and H uman Services, 1995). Students who at times may become bored or disinterested in their classes may still come to school regularly, have a sense of school spirit, and adhere to school rules because of their extracurricular activities.

Participation in extracurricular activities may help students see college in their future. Colleges often use participation in extracurricular activities as a factor in admissions decisions and encourage students to participate in these activities on campus, thus contributing to the campus community ( $\mathrm{H}$ ayden, 1995). M any colleges have stated that high school credit and achievement in the fine arts, for example, are significant considerations for admissions ( $\mathrm{N}$ ational Federation of State $\mathrm{H}$ igh School Associations, 2001).

African American students participate in extracurricular activities at similar rates to white students. Although over half of African American and white high school students report participating in a school sponsored club or athletic team, $\mathrm{H}$ ispanic students are less likely to participate in these activities (Brown \& Theobald, 1998). Participation is also lower among urban minority high school students. Students in urban schools are least likely to participate in extracurricular activities. Because of limited funds, many urban schools offer fewer athletic teams and activities such as school yearbook or newspaper (L ippman et al., 1996).

\section{Study Findings}

The high school experiences results are presented in Figure 5. Clearly, educators are important factors in postsecondary planning. N early threefourths $(73 \%)$ of students in this study indicated that their teachers were very helpful $(47 \%)$ or somewhat helpful $(26 \%)$ in their college planning. A similar percentage of students $(73 \%)$ noted that their counselors were very helpful $(46 \%)$ or somewhat helpful $(27 \%)$ in their college planning. That these percentages are so similar, given the primary roles of teachers and counselors, is noteworthy. They are also remarkably similar to other findings regarding low-income students' college planning (Berkner \& Chavez, 1997). One might 
conclude that the small numbers of counselors in many urban settings, coupled with their breadth of responsibilities, restricts their ability to provide significant assistance to all students in the college planning process.

Perhaps this is a void that teachers fill in such settings. It seems that in urban high schools counselors and teachers take on the central role of helping students with college plans. It is also likely that these roles may differ in terms of content, process, and timing. Their influence is second only to students' parents.

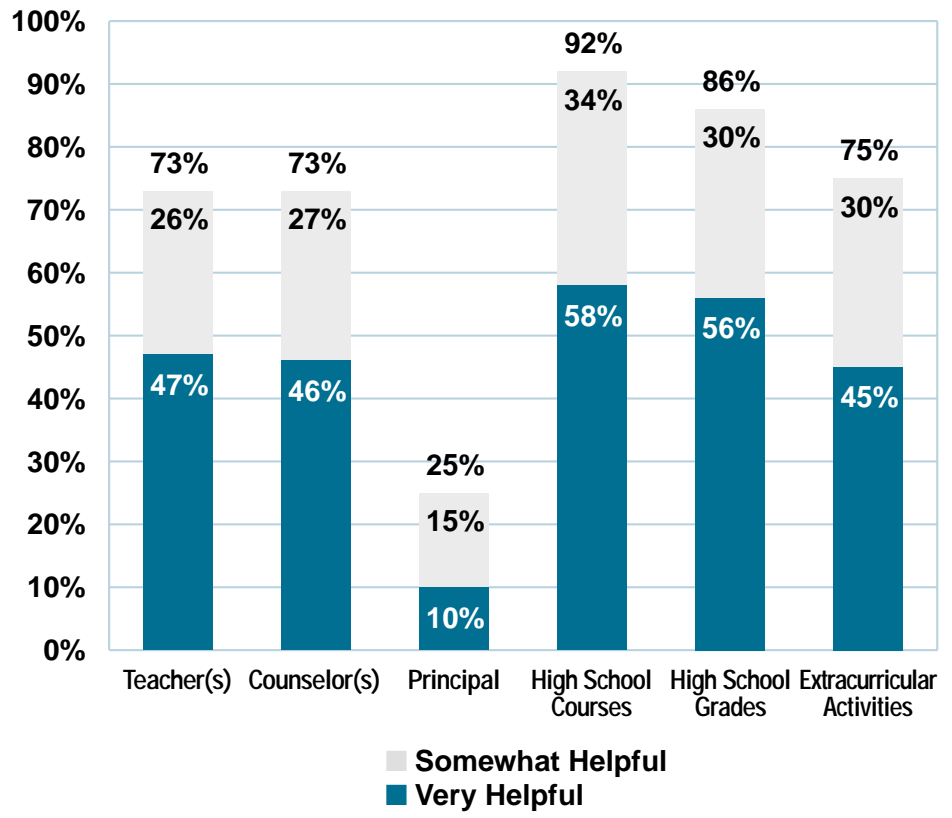

Figure 5: Influence of High School Experiences on Postsecondary Planning

One-quarter of the respondents said their principal was either very helpful $(10 \%)$ or somewhat helpful (15\%) with their college planning process, a finding surprising from several standpoints. Given the extensive set of duties and responsibilities of today's urban high school principals, the fact that onequarter of the students in this study felt that their principals provided a significant degree of help in their college planning is notable. A common perception is that students have very little contact with their high school principal, especially in an urban setting with larger schools, significant administrative issues, and a vast array of student needs. These results, plus the anticipation that the more primary role of principals is to facilitate the resources required to empower college planning, suggests that principals have had a substantial influence and multiple set of roles in their students' transitions from high school to college.

Overall, the students in this study reported that teachers and counselors (and to a lesser extent, principals) were key factors in their college planning. The findings from the focus group interviews indicated that many students described an "interested adult," often in the school, who identified them as having the potential to succeed in college and walked them through the college planning process. This person may be the college counselor in the high school, another school counselor, a specific teacher, a coach, the high 
school principal, or a director/adult in a college planning program such as U pward Bound. The "interested adult" helped ensure that they took college preparatory courses, prepared for college admissions tests, and visited college campuses. This person served as a key information source for students and helped them select colleges, arrange campus visits, complete college applications, process financial aid forms, and often wrote letters of recommendation.

Students reported that high school courses or classes taken were very helpful or somewhat helpful for nearly all students (92\%) in the college planning process. F ifty-eight percent of students indicated that their high school courses were very helpful, and $34 \%$ indicated that their courses were somewhat helpful in their college planning decisions. Students responded similarly (86\%) about their high school grades. The findings show that $56 \%$ of students indicated that their high school grades were very helpful, and 30\% found these grades somewhat helpful in their college planning decisions.

These findings provide several implications for postsecondary planning. F or instance, taking college preparatory courses can serve as a stimulus for college awareness and college planning. In addition, the specific course content might influence students to consider careers and college majors related to these courses, and thus indirectly influence the college exploration and planning process. F urther, grades reflect performance, which students can categorize into areas of academic strength and weakness. Perceived areas of academic strength, much like interesting courses, can foster career and college major exploration and further stimulate the overall college planning process.

Students in the focus groups reported that some of their high school courses had a college planning component. F or example, some students said that they wrote college application essays in their E nglish classes. Others noted that their high school offered courses or special workshops devoted to college planning. In these courses, students

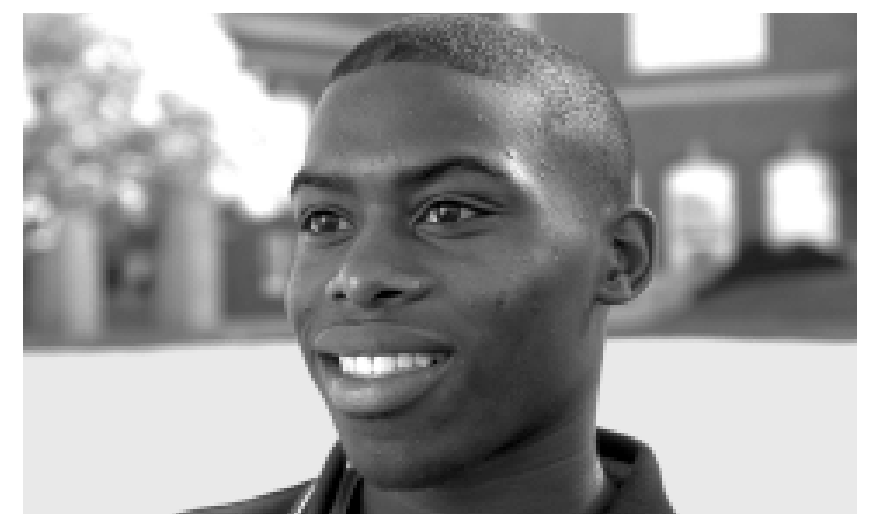
researched colleges and other options after high school (employment, military service). Students even proceeded through all the steps of applying to college in some courses.

Courses and grades also became central in the focus group discussions when students were asked what advice they would give current ninth graders about their college planning. They unanimously responded that ninth graders need to start preparing for college early. $M$ any said that they had low grades during their freshman and sophomore years, and as a result took less rigorous courses or repeated some courses. Some students did not even realize that the high school grade point average is cumulative.

$\mathrm{H}$ igh school extracurricular activities in this study played a significant role in students' college planning decisions. N early $90 \%$ of the students participated in some extracurricular activity in high school. This finding differs from earlier 
research (B rown \& Theobald, 1998; L ippman et al., 1996) in that far greater numbers of urban minority students in the present study were involved in extracurricular activities. This finding may be partly because the students in this study were college bound. H owever, it also may be that many saw extracurricular activity participation as part of overall academic development, connection to the school environment, and a significant aspect of the high school to college transition.

Three-quarters of the students indicated that participating in high school extracurricular activities was very helpful $(45 \%)$ or somewhat helpful $(30 \%)$ in their college planning. These findings clearly suggest that extracurricular activity participation is a source of postsecondary planning information for urban minority students. Students are considering their extracurricular involvement as they make decisions about colleges to attend, areas they may want to study, activities they want to pursue in college, and careers beyond postsecondary education. 


\section{6 \\ Study Results: College Planning Resources}

\section{College Admission and Planning Measures}

The ACT Assessment measures E nglish, mathematics, reading, and science reasoning achievement. Students use the results as part of the college application process by selecting colleges to receive ACT score reports. The ACT Assessment score report also contains information about the colleges students have selected. This information includes, for each institution, an estimated rank for the students' ACT Composite score, the high school grade point average for the freshman class, tuition costs, and the percent of students receiving financial aid. Students also receive educational and career planning information based on the results of their ACT Interest I nventory, stated career plans, and how these factors relate to the ACT World-of-Work M ap.

$M$ any colleges and universities use the ACT Assessment as a significant part of the admissions process (B reland, M axey, Gernand, Cumming, \& Trapani, 2002; B reland et al., 1995). In making admissions decisions, most colleges consider test scores with other criteria such as high school coursework, grades, class rank, extracurricular activities, essays, and letters of recommendation.

Throughout their school years, students may also take numerous standardized achievement tests to assess their academic performance. They may also complete interest inventories to assist in college planning and career exploration. Students often take EXPLORE ${ }^{\circledR}$, for example, in eighth or ninth grade to help them plan their high school curriculum. $M$ any sophomores or juniors take PLAN to further assess their academic performance. Such measures help students begin their college exploration and planning, select high school courses, and prepare for college admissions and placement tests.

School districts often employ a comprehensive approach to continuous assessment and college planning information. The Chicago Public Schools, for example, use the ACT E PAS/E ducational Planning and Assessment System ${ }^{\circledR}$ across grades nine, ten, and eleven (using EXPL ORE , PLAN, and the ACT Assessment, respectively) to provide a stream of information to use for course planning, career interests, and college preparation. Also, some states use assessments to assist students in college planning and to assess academic progress. The Prairie State Achievement E xamination in Illinois uses the ACT Assessment with all public high school juniors and has identified many students who were not considering postsecondary training, but whose scores would enable them to take advantage of such educational opportunities.

African American and $\mathrm{H}$ ispanic students are often not well prepared for college admissions tests and often score below their white peers. $M$ any have not taken rigorous courses that would enable them to perform well on these tests and report not preparing for the tests (G ándara \& López, 1998). They may not fully realize that these tests are an integral part of the college admissions process and consequently fail to prepare for them. They may also 
complete these tests later in the admissions cycle, when options and opportunities may be reduced. Conversely, they may recognize the importance of the tests but lack the necessary information to prepare adequately for them and to use the results effectively in their college planning.

\section{College Information Resources}

Computer software programs and the Internet have become important resources for college planning information. $M$ any programs have databases that describe academic programs, student body characteristics, financial aid availability, housing, extracurricular activities, and college social life. Students can often generate a list of potential colleges and universities by entering background information such as grade point average, admissions test scores, academic and career interests, as well as desired college characteristics such as size, geographic location, and percent of students receiving financial aid. Some programs also help students consider career options by relating their skills, talents, and interests to college majors and occupations.

Other programs (e.g., DISCOVE ${ }^{\circledR}$ ) help students determine areas of career interest and then recommend steps needed for educational and career planning. M iddle school students can use such programs to learn about career planning, assess educational and career interests, explore occupations, and consider courses for high school. $\mathrm{H}$ igh school students can determine types of colleges to attend, chart a plan of study, and evaluate labor market options. $D$ atabases for these programs often include extensive information about occupations, college majors, schools and training institutions, financial aid and scholarships, and military options.

The Internet has rapidly become a primary resource to help students with college planning. I nstitutions have websites with admissions information, academic department and program descriptions, student life characteristics, and facts about the school in general. College course catalogs, bulletins, and admissions applications are often featured online. $M$ any colleges offer virtual tours where students and parents can navigate through video clips of the campus and surrounding community. The Internet provides an added advantage in that it gives students a constant up-to-date view of events on campus. They can often read the student newspaper, see what the important topics are on campus, and learn what activities are occurring, such as athletic events, theatrical productions, and special lectures.

The Internet not only serves as a college information resource, it allows students to communicate with others on campus. Counselors, parents, and students can request information about the school via e-mail and communicate with current students and professors about specific academic programs or extracurricular activities. The Internet exposes students to an interactive view and feel for campus life that is far more dynamic than what has traditionally been found in print publications. 


\section{Pre-College Programs}

N umerous government and locally-supported pre-college programs have been implemented to help minority and low-income students obtain and utilize college planning information. These outreach programs, which take place when students are either in middle school or high school, help prepare them for college- often outside of regular classroom instruction. There are hundreds of pre-college programs designed to increase college going among underrepresented groups. Some are sponsored by private organizations such as the I $\mathrm{H}$ ave a D ream, Project GRAD, and A B etter Chance programs. Others are federal initiatives such as U pward Bound and Talent Search.

$M$ any colleges offer some outreach programs for minority and low-income communities to enhance students' academic skills and increase their college awareness. Other programs are the result of community-based initiatives and partnerships between businesses and local schools (Gándara, 2001). These programs use various practices to enrich students' school experiences, keep them in school, encourage them to think about college, and help them to make successful transitions from high school to college.

Since the 1960s, U pward Bound programs have helped students successfully complete high school and enter college. The goal of U pward B ound is to increase the rates at which targeted students enroll in college by providing basic support throughout the college planning and admissions process (M cE Iroy \& Armesto, 1999; M yers \& Schirm, 1999). U sually sponsored by local colleges, these programs provide students with traditional academic instruction, tutoring, counseling, financial aid information, and career and college planning information. Throughout high school, students in these programs regularly participate in activities on college campuses and often live in college residence halls during the summer months.

U pward Bound participants tend to take a slightly more rigorous high school curriculum than do students with similar academic backgrounds (M yers \& Schirm, 1999). Among $\mathrm{H}$ ispanic students, participation in U pward B ound has increased their educational expectations and given them a clear sense of available college options. The U pward B ound $M$ ath/Science Program establishes U pward Bound centers designed to strengthen the mathematics and science skills of poor and minority high school students. This component of U pward Bound seeks to help students recognize and develop their potential to succeed in mathematics and science related fields and to encourage them to pursue college degrees and careers in these areas.

Other pre-college programs such as Talent Search identify students from similarly disadvantaged backgrounds who have the potential to succeed in college, but may have not started the college planning process. They help students with academic, career, and financial counseling to help them graduate from high school and enroll in college. 


\section{Study F indings}

The findings for the perceived value of college planning resources are shown in Figure 6. The ACT Assessment was of significant help to students, as over two-thirds felt that their results were either very helpful $(29 \%)$ or somewhat helpful (39\%) in postsecondary planning. Among those students $(75 \%$ in this study) who took other college planning tests such as PLAN, 61\% found these tests to be very helpful (22\%) or somewhat helpful (39\%) in college planning.

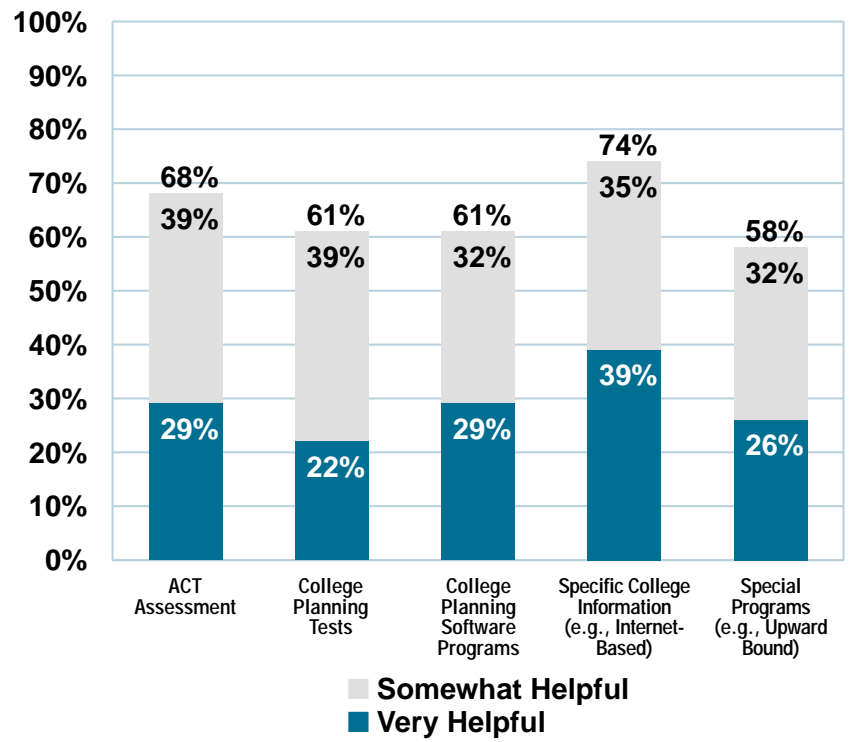

Figure 6: Influence of College Planning Resources on Postsecondary Planning

The results seem to indicate that, despite concerns and criticisms about college admissions tests and minority student performance, the urban students in this study generally found the ACT Assessment helpful to them in their college planning and decision making. Of those students who had completed other tests such as PLAN, a majority found them to be helpful as well. It is possible that the comprehensive nature of the ACT Assessment and PLAN and their integrated emphases on academic achievement, college planning, and career exploration provide a breadth of tailored information that students can use for postsecondary planning. These results, in fact, resemble those of an earlier study of a similar college planning and admissions measure used in the state of Washington that also provided multiple levels of academic and college planning information for students (N oeth et al., 1984).

Less than half of the students (45\%) used college planning software programs such as DISCOVER. The findings show that $61 \%$ of these students found such programs to be very helpful $(29 \%)$ or somewhat helpful (32\%) with their college planning. E ighty-three percent of the students in this study reported using specific college information including some found via the Internet. Roughly three-quarters of these students found this information to be very helpful $(39 \%)$ or somewhat helpful (35\%) in their college planning process.

These combined findings suggest that a majority of urban African American and $\mathrm{H}$ ispanic college-bound students have access to computers and are using the Internet as part of their postsecondary planning. $M$ any students are 
familiar with computer-based postsecondary exploration and planning applications that provide overviews of numerous colleges and universities, convey college and career planning information, and help students learn about financial aid opportunities and select specific colleges to explore.

The focus group discussions revealed, however, that many students still lack accurate college planning information. Some were unfamiliar with postsecondary opportunities. Some did not know the difference between two-year and four-year colleges. In some cases it seemed students had haphazardly chosen a college. Several planned to attend colleges they had never visited or knew very little about. These students may have received a college viewbook or reviewed a college website, yet were unaware of academic programs that interested them or other opportunities the colleges offered.

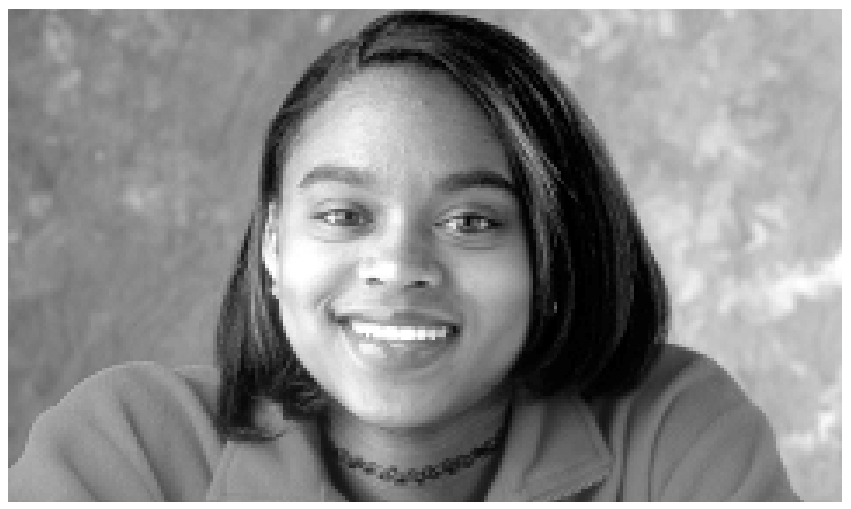

Less than half $(42 \%)$ of the students in this study indicated that they participated in special pre-college programs such as U pward B ound or Talent Search, a finding that suggests that while many college-bound urban African American and $\mathrm{H}$ ispanic students have been exposed to some type of pre-college program, the majority have not. Fifty-eight percent of the participants found these programs to be very helpful $(26 \%)$ or somewhat helpful (32\%). Often these programs gave students their first exposure to a college campus, initial and consistent college planning information, and guidance throughout the college application process. Unfortunately, though programs targeted at low-income students, historically underrepresented minorities, and potential first-generation college students should ideally begin in middle school, Perna (2002) found that only one-third of such programs first enroll students prior to the eighth grade. 


\section{7 \\ Study Results: College Costs and Financial Aid}

F or many urban minority families, costs present a major obstacle to attending college. $\mathrm{M}$ any students and parents perceive that they cannot afford the costs associated with college- such as application fees, tuition, room, board, books, and other necessary expenses. Costs can affect whether and how students approach college exploration and planning. Students often choose to attend a community college or a four-year commuter college to keep costs down.

M ost colleges admit students based on their academic record, not their financial need (Breland et al., 2002; Breland et al., 1995). Considerable federal, state, and school-based financial assistance is available for eligible students. Nationally, $86 \%$ of low-income students receive federally supported financial aid in the form of grants and loans to attend college (Choy, 2000).

College financial aid generally consists of grants, scholarships, federal work study, and loans. The federal government awards the Pell Grant, and the amount students receive depends on financial need, cost to attend school, student status, and plans to attend for a full academic year or less. The F ederal Supplemental E ducational Opportunity G rants (F SE OG) provide grant aid for students with exceptional financial need, with the amount depending on financial need and the funding at their colleges or university (College Board, 2000; U.S. D epartment of E ducation, 2001c). In addition, most states offer some form of grant assistance for residents.

M ost colleges offer scholarships to outstanding students. Full or partial scholarships are often based on one- or some combination of-these factors: academic record, participation in specific extracurricular activities such as athletics and community service, and financial need. $M$ any private foundations and community organizations also offer scholarships to outstanding students. The criteria for awarding scholarships are typically determined by the organization. A number of states also offer tuition scholarships for students with high grade point averages and high scores on college admissions tests.

F ederal Work Study provides part-time jobs for students with financial need. Through this program students earn money to pay for educational expenses by working part-time on campus or with a nonprofit or public agency. The F ederal Work Study program encourages community service work and jobs related to students' field of study; award amounts vary according to financial need and funding level at the school.

The federal government supports low interest loans that students begin repaying when they graduate, leave school, or drop below half-time status. Through the Perkins L oan Program students can borrow funds for college depending on their financial need and the college funding level. M ost colleges participate in either the F ederal F amily E ducation L oan Program or the William D. F ord F ederal D irect L oan Program. In these programs, students can borrow money from banks and the government pays the interest while 
they are in school (U.S. D epartment of E ducation, 2001c). Students can borrow additional money through unsubsidized loans on which the interest accumulates immediately. Parents can borrow money for educational expenses through the PL US L oans Program. And parents and students can also obtain private loans to pay for educational expenses.

In the 1970s, the federally funded Pell Grant was often enough to cover a student's tuition expenses. H owever, the value of the Pell G rant has not kept up with rising college costs, and today the maximum Pell Grant may cover only one-third of educational costs (King, 1996). E ven with the range of financial aid resources, many low-income students have considerable unmet financial need. This often causes them to work longer hours or borrow from other sources to pay for college (Choy, 2000). M ost high school students expect to hold jobs in college to help pay for educational expenses (H esel, 1998).

In the early 1980s, federal college aid shifted from grants to loans that students must repay once they finish college. Student loans thus have become the most common form of financial aid for students. M any low-income students may be reluctant to take on a sizeable student loan with long-term payback requirements if they come from families where borrowing is either uncommon or difficult to manage. Perna (2000) reports that financial aid in the form of loans appears to reduce the probability of enrolling in college for African Americans but is unrelated to enrollment for $\mathrm{H}$ ispanics and whites.

Low-income parents and students often report that they do not receive adequate information about financial aid. $M$ any minority students lack information about application procedures as well as financial aid resources (Cabrera \& La N asa, 2000). Thus, these students often do not know what financial aid is available and consequently perceive that they cannot afford to attend college. $M$ any high achieving lowincome students are more likely to enter the military than college because of college costs. Low-income students who are not offered financial aid at four-year public institutions often do not attend any college. H owever, when these same students obtain financial aid information and receive grants and loans, they are likely to attend college (Akerhielm et al., 1998; Choy, 2000).

All federal financial aid programs and most state and institution-based grants require students to complete the F ree Application for F ederal Student Aid (FAFSA). This form - which students can complete either on paper or via the I nternetrequires students and parents to provide financial information such as income, assets, and debts. The information from the FAF SA is used to determine the Expected $\mathrm{F}$ amily Contribution ( $\mathrm{EFC}$ ) - the amount of money it is calculated that students and families can reasonably contribute toward their education. 
Students and parents report that financial aid forms can be difficult to understand and complete. This is especially the case for those minority parents whose first language is not E nglish (Ginorio \& H uston, 2001). Students often do not appreciate the importance of adhering to financial aid and scholarship deadlines, and may be rendered ineligible for financial assistance solely because of late applications and missed deadlines.

\section{Study Findings}

As shown in Figure 7, college costs and financial aid availability were major issues in urban African American and $\mathrm{H}$ ispanic students' college planning decisions. Well over half of the students surveyed $(57 \%)$ indicated that college costs were a major obstacle, and over one-third (36\%) said that college costs were a minor obstacle in their college planning.

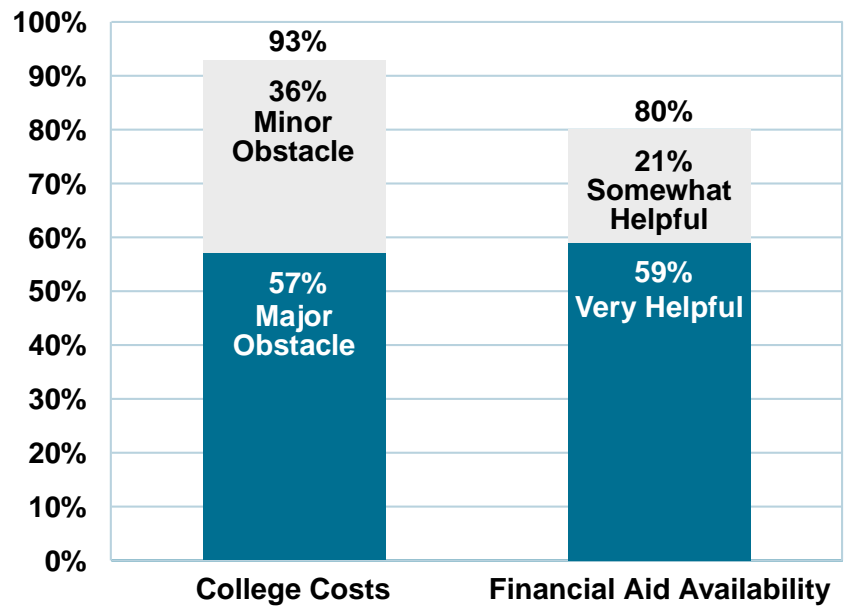

Figure 7: College Costs and Financial Aid Availability

The majority of students in the study (80\%) reported financial aid availability as a very helpful $(59 \%)$ or somewhat helpful $(21 \%)$ factor in their college planning activities. These findings further confirm that financial aid is essential for these students to attend college. While these students perceived costs as an obstacle toward attending college, they also saw that financial aid could make their plans a reality.

All the school districts in this study had a high percent of students receiving free or reduced-cost lunch, which suggests that most students were economically disadvantaged to some degree. In the focus group interviews, students indicated that their families had few economic resources to contribute to college expenses. They said that they could not meet college costs such as admissions test fees, college applications, tuition, room, board, and other expenses. $M$ any students perceived college as unaffordable, yet still planned to attend. Students were often reluctant to apply for student loans, not understanding the concept of borrowing money to pay for college as investments in their future.

The focus group interviews further revealed that many students had problems adhering to deadlines. Registering for the ACT Assessment, completing the FAF SA, applying for local scholarships, completing college applications, and securing letters of recommendation were some of the college planning 
activities that students had difficulty completing by a specific date. Students repeatedly missed out on educational opportunities and financial support because they did not apply or register on time. As late as $M$ ay and June of their senior year, many students' college plans were uncertain. M any students had not taken the ACT Assessment until spring of their senior year, had not applied for financial aid, and were unsure which college they would attend. E ven among students who had been admitted to a college, many had not received financial aid packages and had not made housing arrangements. Some students had not yet applied to the college they planned to attend. Students who miss application and financial aid deadlines-or who delay actions regarding registration requirements- jeopardize their chances of enrolling at their chosen college. 


\section{RECOMMENDATIONS}

This study examined the particular postsecondary planning needs and influences of urban African American and $\mathrm{H}$ ispanic graduating high school seniors. It offered the transitional focus of a seamless $\mathrm{P}-16$ education system as a backdrop for analysis and consideration. Results were tied to other research and presented as a series of findings across four areas of influence: family and friends, high school experiences, college planning resources, and college costs and financial aid. On the basis of the conclusions and related research, we offer one overall and thirteen specific educational policy recommendations. These recommendations represent the elements of a systematic and systemic approach that can directly support the postsecondary exploration and planning of urban African American and $\mathrm{H}$ ispanic students.

While the overall recommendation we strongly endorse as an absolute standard, districts and schools likely will prioritize the thirteen specific recommendations according to their particular combinations of characteristics, programs, and resources. F urther, many of these recommendations, as stated or slightly modified, can be appropriate for the postsecondary planning needs of all students.

\section{Overall Recommendation}

\section{Districts should have and should implement an Educational Transitions Strategic Plan that specifically includes and focuses on college exploration and postsecondary planning activities, programs, and outcomes that begin at least in the middle school and continue throughout high school.}

Clearly, educational transitions are an essential aspect of a seamless $\mathrm{P}-16$ system. This notion is naturally implied in, and must be an integral part of, any such system. M uch of the P-16 literature rightly focuses on the importance of achievement, standards, assessment, curricula, and teacher training across a seamless system. H owever, there seems to be a gap in bringing all of these aspects to bear (as well as involving parents, community organizations, and businesses) in facilitating educational transitions-specifically in developing and enhancing a comprehensive postsecondary planning program. This challenge seems to be further exacerbated in urban areas that serve significant African American and $\mathrm{H}$ ispanic populations whose resources are stretched by multiple demands not always encountered in rural and suburban settings.

This recommendation urges school districts to have and to implement an E ducational Transitions Strategic Plan that incorporates school staff, resources (e.g., materials, assessments), parents, community organizations, businesses, local two- and four-year colleges, and other entities (e.g., externally-funded, college-planning program opportunities) into a comprehensive college exploration and planning program that begins in the middle school and continues throughout high school. The creation of this plan should include all constituents and stakeholders (e.g., administrators, teachers, counselors, 
parents, etc.), should be announced to all involved parties (e.g., students, parents, staff, etc.), and should be published in multiple venues to ensure widespread circulation. The plan should provide extensive details about each element of this plan, how the elements tie together, the roles of each participant (e.g., teachers, mentors, activity leaders, counselors), the multiple-year sequence of activities, the expected outcomes, and how it will be evaluated.

F urther, it would not be unreasonable to expect state departments of education to address these college exploration and postsecondary planning issues from a more global perspective to provide both leadership and concrete program examples to school districts. The implementation of a comprehensive $\mathrm{P}-16$ system requires leadership from the top down. Aside from joint collaboration with the postsecondary element of a seamless education system, state departments of education must foster seamless transitions both within the $\mathrm{K}-12$ system and into postsecondary education. O ne way to accomplish this is to develop a Statewide Plan for E ducational Transitions that focuses on college exploration and postsecondary planning activities, programs, and outcomes for grades 6-12, and that serves as a model upon which school districts can build and enhance their own programs.

The successful undertaking of a comprehensive E ducational Transitions Strategic Plan at the district and state level will likely require formally documented and assigned leadership of such responsibilities. It seems appropriate, given the comprehensive nature (and commensurate need to coalesce resources) of college exploration and college planning across grades $6-12$, that those in administrative positions be assigned such responsibilities.

Under our recommendation, these administrators would be required to direct the establishment, refinement, and implementation of an E ducational Transitions Strategic Plan, and would need to bring together all constituents and stakeholders to do so. The requisite responsibilities would cut across and involve teaching and student service staff, curriculum, related school resources, assessments, and sponsored inside- and outside-of-school activities. These administrators would also work closely with parents, community organizations, and businesses in the implementation of this plan- as well as seek, on behalf of the school district or state, external funds to facilitate college planning programs and activities. F inally, districts and states would designate these administrators as the chief educational transition liaisons within their K-12 systems: that is, they would be the primary interfaces between $\mathrm{K}-12$ and the postsecondary education community in all P-16 system educational transition planning and implementation. 


\section{Specific Recommendations}

Schools should make concerted, systematic, and continuous effortsthrough an array of programs and information resources- to explain and reinforce the postsecondary planning process to parents.

Schools should recognize that many parents might not know how to help their children plan for postsecondary education. Schools must develop and implement programs, starting no later than the middle school, to involve urban minority parents in their children's college planning process. These programs must be information based, must reinforce key messages about the important steps in the college planning process, and must be repeated throughout the school year and scheduled at different times to accommodate parents' schedules. These programs should be designed to effect long-term, systematic change in the culture and climate of schools rather than to intervene in an identified need on a short-term basis (Somers, C ofer, $\&$ VanderPutten, 2002). The key information points in the postsecondary planning process that can be developed in depth by the schools, given their relative populations and resources, are:

- The importance of a postsecondary education

- The college admissions process

- Planning a middle school and high school course of study

- Exploring students' values, interests, and abilities

- Tests involved in early college planning and in the college admissions process

- The importance of school and community activity involvement

- Considering careers and college majors

- Paying for college costs

- Visiting colleges

- The resources available in the school, on the Internet, and in the community for postsecondary exploration and planning

Schools must also be sensitive to cultural, language, and socioeconomic differences when providing college planning information. Parents may feel uncomfortable and uncertain, and may be unable to take an interest in their children's postsecondary planning if the process does not fit with their cultural and educational experience. Schools must work to overcome these barriers and do everything possible to involve parents in the college planning process.

Schools should facilitate informed and mentored peer networks, beginning at least in middle school, that support school performance and postsecondary planning.

Students often rely on each other for college planning information. Thus, it is important beginning in middle school that students understand the elements of postsecondary exploration, preparation, and planning. They must have clear, accurate, and timely information at all key stages of this process. U rban African American and $\mathrm{H}$ ispanic students in particular must have current, structured, and continuous information-as well as constant school-based support- to facilitate postsecondary exploration, planning, and decision 
making. One way to foster this is to create educational planning groupsinvolving teacher, counselor, or principal mentors, starting no later than the middle school (and preferably earlier) - that begin to share postsecondary information and resources. As students transition into high school, their mentored groups can become more structured in terms of college planning stages and timelines. Such groups readily lend themselves to on-campus visits and learning experiences. They might also have recent graduates share their college experiences with current students.

\section{D istricts need to provide counselors, starting in middle school, whose major tasks are to deal with the college exploration and postsecondary planning process.}

Starting in the seventh grade, districts should provide counselors specifically to help students plan courses for high school and begin thinking about postsecondary training. They can help middle school students explore career options and select classes that will prepare them for college. E arly exposure to postsecondary planning is especially helpful in low income and minority schools, where many students may be first-generation college and their parents may not have the necessary tools to help them plan for college. $M$ any schools provide counselors who only deal with postsecondary planning issues, who ensure that students take college preparatory classes, prepare for and take college admissions tests, meet with college admission officers, and complete college applications, financial aid forms, and scholarship applications. One way to further augment this emphasis is to provide

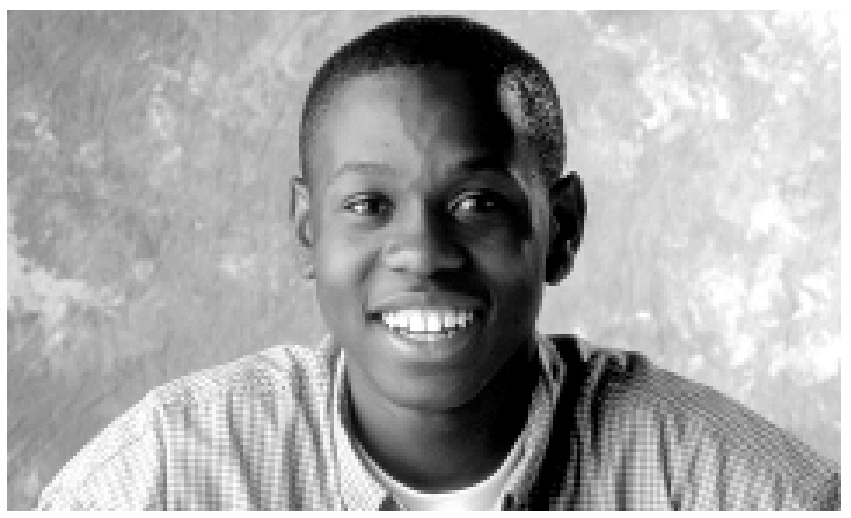
teachers with basic postsecondary exploration and planning information through workshops and related activities, perhaps supported by admissions and financial aid staff members from local two- and four-year colleges.

Schools should further limit the number of students a counselor can serve by setting an acceptable standard counselor-to-student ratio. The American School Counselor Association recommends that this ratio not exceed 1:250. (H owever, the national average is currently 1:560, and urban schools far exceed it!) The N ational Association for College Admission Counseling recommends an ideal counselor-to-student ratio of 1:100 and sets a maximum of $1: 300$.

\section{Counselors, teachers, principals, and other personnel should work to establish both formal and informal relationships with their students to assist them in various phases of the postsecondary planning process.}

Though the relationships can be structured around classroom learning, school projects, and formal postsecondary planning activities (e.g., course selection), they can also include more informal experiences such as extracurricular activities, Internet groups, and community service projects where educators can assume more of a mentoring role. This accords with the suggestion of the $\mathrm{N}$ ational Association of Secondary School Principals that every child have a 
"personal adult advocate" in school, reflecting that organization's desire to personalize the high school experience for students (1996). E ducators have a breadth of college-related experiences and suggestions-from both a personal and professional perspective - that can benefit students (and their parents) as they encounter different stages of the college planning process.

Low income and minority students often rely primarily on teachers and counselors for postsecondary information. Students who have positive and consistent relationships with these and other educators may find it easier to obtain the information they need to plan for postsecondary training. Several college outreach programs have found that the most important component of any program is a long-term relationship with a knowledgeable adult (Gándara, 2001).

\section{All high school students should be required to begin (in the middle school) and complete as challenging a college preparatory core curriculum as possible so that they will be adequately prepared for college success.}

This preparatory curriculum, in which students begin as early as eighth grade to take as rigorous a set of coursework as possible, should include algebra and a foreign language. Taking algebra in eighth grade, for example, is strongly associated with taking advanced mathematics in high school, which, in turn, is strongly associated with a higher likelihood of attending college (Choy, $\mathrm{H}$ orn, N uñez, \& Chen, 2000).

School districts in M ilwaukee and Providence, for example, require all ninth graders to complete algebra I and all tenth graders to complete geometry as part of the E quity 2000 Program. This change in course requirements has nearly tripled algebra and geometry course-taking in these districts. $M$ any states and districts have expanded their high school graduation requirements to ensure that their graduates are prepared for college. Chicago students must perform near grade level in reading and math before they can begin high school (R oderick, Bryk, Jacob, E aston, \& Allensworth, 1999), thus reducing the number of entering students who are unprepared for the high school curriculum. Beginning in 2004, all Texas students must enter high school with a plan to complete at least the state's Recommended High School Program. South Carolina students can take either a college preparatory sequence or a technical course, thus eliminating the general education track. Other states, including Georgia and N orth Carolina, have also eliminated the general curriculum track (Christie, 2000).

$M$ any colleges and universities recommend that high school students complete four years of E nglish (with an emphasis on writing and literature), four years of math (with at least one course beyond algebra II), three to four years of laboratory science, two to three years of social studies (with one course in world history), three years of one foreign language, and at least one year of fine arts courses. Such a curriculum helps students develop the critical thinking and writing skills they will need to compete successfully in college. 


\section{School staff should help students to recognize that performance in high school coursework is reflected in grades, and that these grades are important indicators for educators and others of students' ability to succeed in subsequent coursework and in college.}

Teachers, counselors, principals, and other school staff should reinforce with students and parents the importance of their best performance in the most challenging coursework. This topic should be an ongoing part of college planning activities, beginning at least in the middle school. E ducators should help students and parents realize the implications of school performance and grades in demanding courses for both high school planning and postsecondary opportunities. Students need to understand that their grade point average is cumulative throughout high school, that specific course grades are often determinants of the ability to complete additional and related coursework, and that grade point average and specific course grades will affect college admissions.

Schools should systematically review academic progress with students and parents and relate it to college planning. $M$ any students approach senior year unaware that their previous grades are cumulative and that colleges see their entire high school record. F urther, educators should help students understand how their grade point average, class rank, and test scores compare to those of applicants at the colleges they are considering (ACT, 1999).

\section{Schools should integrate a postsecondary planning component into extracurricular activities.}

Schools should offer as wide a range of extracurricular activities as possible and encourage all students to participate in those that interest them. Activities provide an excellent opportunity for school staff to encourage students to initiate college exploration and postsecondary planning activities, and also provide valuable college planning information based on personal and professional experience. Postsecondary planning segments of extracurricular activities need not be lengthy or detailed, but they should be structured. F or example, they might involve asking participants to consider the interests and skills that attracted them to the activity initially and how this might affect their plans for a college major, college activities, and selection of specific colleges. L eaders of these activities might create opportunities for participants to interact with former students who were involved in these same activities and who are now in college. They can provide information about college planning and how the particular extracurricular activities helped their planning.

$M$ any after-school programs have a college planning component that connects students with colleges through campus visits, college student tutors in the high school, motivational speakers, and other activities. Such programs expand learning opportunities, link students with adult educators, encourage strong family involvement, and build partnerships between schools and the local community (Butty, L aPoint, Thomas, \& Thompson, 2001). Such after-school programs, however, should endeavor to flexibly reach out to students whose family and/or work obligations might limit their participation. 
Schools should provide information on college admissions tests, including registration dates, how to prepare, and how test scores are used.

Counselors and teachers need to make students aware of the importance of college admissions tests and the role of test scores in college planning and admissions. Students should understand what the tests measure, when and where they are administered, the relationship between test dates and college application deadlines, how colleges use the information, and the best ways to prepare for the tests.

Schools should use free test preparation materials provided by test publishers (e.g., Preparing for the ACT Assessment; ACT, 2001) with students. Test preparation activities might involve teacher-led groups organized by school counselors and focus on various elements of the tests (e.g., a science teacher discussing the ACT Assessment Science Reasoning Test). Counselors, with help from college admissions offices, might conduct case-study workshops for students and their parents that demonstrate how admission decisions are based on a range of student information and how test scores are used in decision making.

\section{Schools should systematically use test information to help students plan their high school curriculum, identify areas for improvement, consider career options, and plan for postsecondary education.}

Schools should thoroughly explain results and related information from college planning measures and their implications to students and parents. This should be done in a systematic and incremental manner so that students and parents can understand and track progress and change over time, and can continually discuss with educators the implications of performance changes for course planning and college decisions. O klahoma, for example, has implemented its E ducational Planning and Assessment System to help determine if students are on target to succeed throughout high school and in college. Schools use results from EXPLORE, PLAN, and the ACT Assessment to help students select high school courses and begin planning for college. In 2000, Oklahoma students' ACT scores were at their highest level, and minority students had made significant gains (OIson, 2001).

A further way for students to use college planning information in a systematic way is to clarify the relationship between test performance and how this performance aligns with classroom and college readiness skills. Schools and districts can utilize knowledge and assessment alignments from test publishers (e.g., ACT Standards for Transition ${ }^{\mathrm{TM}}$ ) to describe the skills and knowledge associated with various test score ranges to help students identify their own areas of strength and weakness. M any schools currently use such information to help place students into courses, evaluate their own course offerings, plan institutional interventions, evaluate student progress, and prepare students to meet college expectations (ACT, 2000). 
Schools should provide students with information and access to reputable Internet-based and stand-alone computer software programs to assist them with postsecondary planning.

M iddle schools and high schools should provide time throughout the day (including before and after the regular school day) and resources for students to use the Internet and computer-based college exploration and planning programs. To facilitate this process, specially trained staff should be available who possess both the necessary technological skills and an understanding of the college exploration and planning process. They can help students formulate queries, evaluate information, learn how to find specific information, and create their own tailored college planning file. Self-help guides should be available for students and their parents to empower them to use these technological resources away from school.

After-school programs should also have a computer component where students are free to explore educational and other resources via the Internet. Such resources will allow students time outside of the regular school day to navigate the Internet and obtain college planning information. Providing students with access to computers and the Internet can attract an array of middle and high school students to participate in after-school programs. Given that computer clubs are often the most popular organizations in schools (de Kanter, 2001; Kugler, 2001), staff working with these groups should channel some of their activities into helping develop programs, methods, and guides that allow students to more easily use technology in the college planning process.

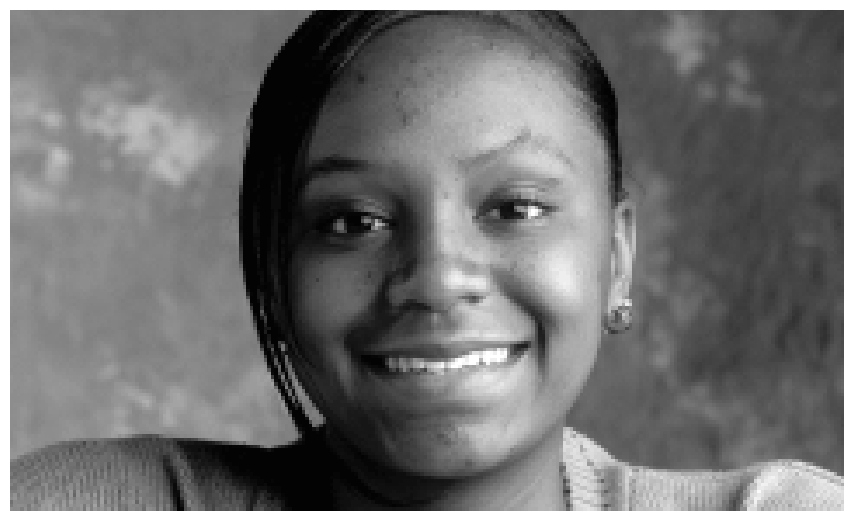

G overnment agencies, businesses, church groups, community organizations, and local two- and four-year colleges should work collaboratively to make pre-college programs available to as many students as possible, as early as possible.

Federal programs such as U pward Bound have successfully increased minority and low-income students' college aspirations and helped them establish relationships with colleges and universities. As shown in this study and others, however, these programs reach a limited number of urban minority students. Clearly, additional funding and support that might come from public and private sectors would allow more urban minority students to participate in these programs.

Collaborations among businesses, community organizations, and institutionssuch as with Project GRAD - can create and foster programs to educate students and parents about college planning topics such as course selection, financial aid, and college visits. Such collaborations, which rely on the experience and expertise of the individuals within these cooperative ventures, can be extremely cost-effective. Such programs, whether governmental or developed collaboratively by organizations and institutions, may need to expand their scope not just to increase college aspirations but to help students 
succeed throughout middle school and high school so they will be adequately prepared for the transition from high school to college. After-school programs, in particular, that have focused on helping students prepare for college have been effective in supporting and enhancing this transition (Pederson, de Kanter, Bobo, Weinig, \& N oeth, 1998).

\section{Schools must continually reinforce with students and parents that financial aid is available to help pay college costs.}

Students and parents should know that financial considerations do not have to be barriers for college attendance. M ost students expect to attend college, and schools must stress systematically and repeatedly through their college planning programs that there are many resources available to help pay college costs. Students should be encouraged to consider and take advantage of all financial aid options available. Low-income students and their families may be reluctant to take out student loans and may not understand the process. School staff, alone or in collaboration with local banks and community agencies, can assist parents and students to understand loan ramifications and assist them with loan applications. $\mathrm{H}$ igh schools can help students understand money management when they arrive in college by developing simulated budgets that reflect financial aid provisions.

The field of financial aid is complex and always changing. F inancial aid can come from a variety of sources-including governmental, institutional, organizational, and corporate entities. Knowledge of these resources and the ways to access them is necessary for those helping students in the college planning process. School staff must be knowledgeable about financial aid opportunities, the financial aid process, and how to help students and families evaluate financial aid offerings. M any high schools establish libraries of information about scholarships, grants, loans, and other financial aid opportunities (D agradi, 1995). Schools must provide time and support access to staff through workshops, on-site visits, technological training, and networking activities for the acquisition of up-to-date and comprehensive financial aid information, including information about the multiple procedures that students and their families must be aware of and understand to apply for such aid.

\section{Schools must ensure that students are aware of, understand, and meet application deadlines for financial aid.}

$\mathrm{H}$ igh school students and their parents should complete and submit the FAF SA as early as allowable in the process, regardless of their college plans at that time. M any low-income students miss out on Pell Grants, F ederal Supplemental E ducation Opportunity Grants, and Work-Study funds because they apply for these programs too late.

$\mathrm{H}$ igh schools should structure time to take students and their parents through the FAF SA and other pertinent financial aid forms step by step. This may mean schools providing students and parents access to the I nternet after school hours or on weekends to complete the FAF SA online or to receive help in completing the paper-based application. Schools, lending organizations, and community agencies need to reach out to students and parents to explain 
financial aid programs in a clear and concise manner. This theme lends itself to self-contained college night units, open houses, and back-to-school events, as many parents, especially those who are not college educated, may not understand all that is needed for the FAFSA and why such information is required, and may be intimidated by the financial aid process. $\mathrm{H}$ igh schools can develop partnerships with local two- and four-year colleges to help provide such college planning and financial aid information to students and parents. 


\section{BIBLIOGRAPHY}

ACT. (1999). College planning/search book: A workbook and resource for college planning. I owa City, IA: Author.

ACT. (2000). I nterpreting and using test results: Standards for Transition information services guide for school administrators. Iowa City, IA: Author.

ACT. (2001). Preparing for the ACT Assessment. I owa City, I A: Author.

Adelman, C. (1999). Answers in the tool box: Academic intensity, attendance patterns, and bachelor's degree attainment. Washington, D C: U.S. D epartment of E ducation.

Akerhielm, K., B erger, J., H ooker, M ., \& Wise, D . (1998). Factors related to college enrollment. Final report. Washington, D C: U.S. D epartment of E ducation, Office of the Under Secretary.

American School Counselor Association. (1997). The national standards for school counseling programs. Alexandria, VA: Author.

Atanda, R. (1999). Do gatekeeper courses expand education options? Washington, D C: $\mathrm{N}$ ational Center for $\mathrm{E}$ ducation Statistics.

Berkner, L., \& Chavez, L. (1997). Access to postsecondary education for the 1992 high school graduates. Washington, D C: U.S. Government Printing Office.

B owen, W. G., \& Bok, D. (1998). The shape of the river: L ong-term consequences of considering race in college and university admissions. Princeton, $\mathrm{N}$ J: Princeton University Press.

B reland, H., M axey, J., Gernand, R., Cumming, T., \& Trapani, C. (2002). Trends in college admission 2000: A report of a national survey of undergraduate admission policies, practices, and procedures. Alexandria, VA: N ational Association for College Admission Counseling.

B reland, H. M., M axey, J., M cL ure, G. T., Valiga, M. J., Boatwright, M. A., Ganley, V. $L$., et al. (1995). C hallenges in college admissions: A report of a survey of undergraduate admissions policies, practices, and procedures. Washington, DC: American Association of Collegiate Registrars and Admissions Officers.

B rown, B. B., \& Theobald, W. (1998). L earning contexts beyond the classroom: Extracurricular activities, community organizations, and peer groups. In K. Borman \& B. Schneider (E ds.), The adolescent years: Social influences and educational challenges (pp. 109-141). Chicago: The University of Chicago Press.

Brown, R., \& E vans, W. P. (2002). Extracurricular activity and ethnicity: Creating greater school connection among diverse student populations. Urban Education, 37(1), 41-58.

Butty, J.-A. L. M ., LaPoint, V., Thomas, V. G., \& Thompson, D. (2001). The changing face of after-school programs: Advocating talent development for urban middle and high school students. National Association of Secondary School Principals Bulletin, 85(626), 22-34.

Cabrera, A. F., \& La N asa, S. M . (2000). Understanding the college-choice process. In A. F. Cabrera \& S. M . La N asa (E ds.), Understanding the college choice of disadvantaged students (pp. 5-22). San F rancisco: Jossey-Bass. 
Chapa, J., \& L azaro, V. A. (1998). H opwood in Texas: The untimely end of affirmative action. In G. Orfield \& E . M iller (E ds.), Chilling admissions: The affirmative action crisis and the search for alternatives (pp. 51-70). Cambridge, M A:

President and F ellows of $\mathrm{H}$ arvard College.

Choy, S. P. (2000). L ow-income students: Who they are and how they pay for their education. Washington, D C: U.S. D epartment of E ducation, National Center for E ducation Statistics.

Choy, S. P., H orn, L. J., N uñez, A.-M ., \& Chen, X. (2000). Transition to college: What helps at-risk students and students whose parents did not attend college. In A. F. Cabrera \& S. M . La N asa (E ds.), Understanding the college choice of disadvantaged students (pp. 45-63). San F rancisco: J ossey-B ass Publishers.

Christie, K. (2000). Secondary education: Expect more, get more. Phi Delta Kappan, 82(3), 186-187.

College B oard. (1999). Reaching the top: A report of the national task force on minority high achievement. N ew York: Author.

College Board. (2000). Trends in student aid. N ew York: Author.

Cook, P. J., \& L udwig, J. (1998). The burden of "acting white": D o black adolescents disparage academic achievement? In C. Jencks \& M. Phillips (E ds.), The blackwhite test score gap (pp. 375-400). Washington, D C: B rookings Institution Press.

Corbin, S. K., \& Pruitt, R. L. II (1999). Who am I? The development of the African American male identity. In V. C. Polite \& J. E . D avis (E ds.), African American males in school and society: Practices and policies for effective education (pp. 6881). N ew York: Teacher's College Press.

Council of the G reat City Schools, \& ACT. (2001). A decade of ACT results in the nation's urban schools 1990-1999: A report on urban student achievement and course taking. Washington, D C: Author.

Csikszentmihalyi, M ., \& Schneider, B. (2000). B ecoming adult: H ow teenagers prepare for the world of work. N ew York: Basic Books.

D agradi, L. (1995). Planning to meet college costs. In E . R. M atthay (E d.), Counseling for college: A professional's guide to motivating, advising, and preparing students for higher education (2nd ed., pp. 57-79). Princeton, NJ: Peterson's.

de Kanter, A. (2001). After-school programs for adolescents. National Association of Secondary School Principals Bulletin, 85(626), 12-21.

E ducation Commission of the States. (2001). The progress of education reform 19992001: High school curriculum, 3(1).

Epps, E. G. (1995). Race, class, and educational opportunity: Trends in the sociology of education. Sociological Forum, 10(4), 593-608.

E pstein, J. L., C oates, L., Salinas, K. C., Sanders, M . G ., \& Simon, B. S. (1997). School, family, and community partnerships: Your handbook for action. Thousand Oaks, CA: Corwin Press.

F reeman, K. (1999). The race factor in African Americans' college choice. Urban E ducation, 34(1), 4-25.

Gándara, P. (with Bial, D .). (2001). Paving the way to postsecondary education: K-12 intervention programs for under represented youth. Washington, DC: U.S. D epartment of E ducation, $N$ ational Center for E ducation Statistics. 
Gándara, P., Gutiérrez, D ., \& O'H ara, S. (2001). Planning for the future in rural and urban high schools. Journal of Education for Students Placed at Risk, 6(1\&2), 7393.

Gándara, P., \& López, E . (1998). Latino students and college entrance exams: H ow much do they really matter? H ispanic J ournal of Behavioral Sciences, 20(1), 1738.

Ginorio, A., \& H uston, M . (2001). ¡Sí, se puede! Yes, we can - Latinas in school. Washington DC: American Association of U niversity Women E ducational F oundation.

H ayden, T. C. (1995). Peterson's handbook for college admissions (4th ed.). Princeton, $\mathrm{NJ}$ : Peterson's.

H esel, R. A. (1998). Student Poll, 3(3).

H ill, R. B. (1999). The strengths of African American families: Twenty-five years later. $\mathrm{N}$ ew York: U niversity Press of America.

H orn, L., \& N uñez, A.-M . (2000). M apping the road to college: First-generation students' math track, planning strategies, and context of support. Washington, DC: U.S. D epartment of E ducation, $N$ ational Center for $E$ ducation Statistics.

H ossler, D ., Schmit, J., \& Vesper, N. (1999). G oing to college: H ow social, economic, and educational factors influence the decisions students make. Baltimore: The Johns H opkins U niversity Press.

H rabowski, F. A. III, M aton, K. I., \& Greif, G. L. (1998). Beating the odds: Raising academically successful African American males. N ew York: Oxford U niversity Press.

Immerwahr, J. (with F oleno, T.). (2000). G reat expectations: How the public and parents-white, African American, and Hispanic- view higher education. Washington, D C: The N ational Center for Public Policy and H igher E ducation.

Institute for Higher E ducation Policy. (1998). Do grants matter? Student grant aid and college affordability. Washington, D C: Author.

Institute for Higher E ducation Policy. (2001). G etting through college: Voices of low-income and minority students in N ew England. Washington, DC: Author.

Kahne, J. (1999). Personalized philanthropy: Can it support youth and build civic commitments? Youth \& Society, 30(3), 367-387.

Kao, G., \& Tienda, M . (1998). E ducational aspirations of minority youth. American Journal of Education, 106, 349-384.

Kelly, M. P. F. (1995). Social and cultural capital in the urban ghetto: Implications for the economic sociology of immigration. In A. Portes (Ed.), The economic sociology of immigration (pp. 213-247). N ew York: Russell Sage F oundation.

King, J. E . (1996). Student aid: Who benefits now? Educational Record (Winter), 21-26.

Kleiman, N. S. (2001). Building a highway to higher ed: How collaborative efforts are changing education in America. N ew York: Center for an U rban F uture.

Kozol, J. (1991). Savage inequalities: Children in America's schools. N ew York: Crown Publishers.

Kugler, M . R. (2001). After-school programs are making a difference. National Association of Secondary School Principals Bulletin, 85(626), 3-11. 
Lippman, L., Burns, S., \& M cArthur, E. (1996). Urban schools: The challenge of location and poverty. Washington, D C: U .S. D epartment of E ducation, $N$ ational Center for E ducation Statistics.

Lucas, S. R. (1999). Tracking inequality: Stratification and mobility in American high schools. N ew York: Teachers College Press.

M acL eod, J. (1995). Ain't no makin' it: Aspirations and attainment in a low-income neighborhood. Boulder, CO: Westview Press.

M atthay, E. R., \& N ieuwenhuis, M . (1995). Planning extracurricular activities. In E. R. $M$ atthay ( $E$ d.), Counseling for college: A professional's guide to motivating, advising, and preparing students for higher education (2nd ed., pp. 50-56). Princeton, N J: Peterson's.

M CD onough, P. M . (1997). Choosing colleges: H ow social class and schools structure opportunity. Albany, N Y: State U niversity of N ew York Press.

M cD onough, P. M ., Korn, J ., \& Yamasaki, E . (1997). Access, equity, and the privatization of college counseling. The Review of H igher E ducation, 20(3), 297317.

M CE Iroy, E . . ., \& Armesto, M . (1999). Trio and upward bound: H istory, programs, and issues- past, present, and future. Journal of N egro Education, 67(4), 373-380.

M cRobbie, J. (2001). Seamless schooling. L eadership, 30(5), 28-31.

M uller, C., \& Kerbow, D. (1993). Parent involvement in home, school, and community. In B. Schneider \& J. Coleman (E ds.), Parents, their children, and schools (pp. 13-43). Boulder, CO: Westview Press.

M yers, D ., \& Schirm, A. (1999). The impacts of Upward Bound: Final report for Phase I of the national evaluation. Washington, DC: U.S. D epartment of E ducation, Planning and E valuation Services.

N ational Association of Secondary School Principals. (1996). B reaking ranks: Changing an American institution. Reston, VA: Author.

$N$ ational Commission on Excellence in E ducation. (1983). A nation at risk: The imperative for educational reform. Washington, D C: U.S. G overnment Printing Office.

$\mathrm{N}$ ational Commission on the $\mathrm{H}$ igh School Senior Year. (2001). Raising our sights: No high school senior left behind. Princeton, $\mathrm{N}$ J: The Woodrow Wilson $\mathrm{N}$ ational F ellowship F oundation.

$\mathrm{N}$ ational F ederation of State High School Associations. (2001). The case for high school activities. Indianapolis, I N : Author.

N oeth, R. J., E ngen, H . B., \& N oeth, P. E . (1984). M aking career decisions: A selfreport of factors that help high school students. The Vocational Guidance Q uarterly, 32(4), 240-248.

O 'Connor, C. (1997). D ispositions toward (collective) struggle and educational resilience in the inner city: A case analysis of six African-American high school students. American E ducational Research J ournal, 34(4), 593-629.

O 'Connor, C. (1999). Race, class, and gender in America: N arratives of opportunity among low-income African American youths. Sociology of Education, 72, 137-157.

Olson, L. (2001). K-12 and college expectations often fail to mesh. E ducation Week, 20(34), 1,14,16,17. 
Painter, G., \& L evine, D. I. (2000). F amily structure and youths' outcomes: Which correlations are causal? The Journal of H uman Resources, 35(3), 524-549.

Pederson, J., de Kanter, A., B obo, L. M ., Weinig, K., \& N oeth, K . (1998). Safe and smart: Making the after-school hours work for kids. Washington, DC: U.S. D epartment of E ducation, U.S. D epartment of J ustice.

Perna, L. W. (2000). D ifferences in the decision to attend college among African Americans, $\mathrm{H}$ ispanics, and whites. The J ournal of Higher Education, 71(2), 117141.

Perna, L. W. (2002). Precollege outreach programs: Characteristics of programs serving historically underrepresented groups of students. Journal of College Student Development, 43(1), 64-83.

Pipho, C. (2001). State policy options to support a P-16 system of public education. D enver, CO: E ducation Commission of the States.

Riley, R. W. (1999). N ew challenges, a new resolve: M oving American education into the 21st century, The Sixth Annual State of American E ducation Speech. Long Beach, CA.

Riley, R. W. (2000). Excelencia para todos - excellence for all: The progress of Hispanic education and the challenges of a new century. Bell M ulticultural $\mathrm{H}$ igh School, Washington, DC.

Roderick, M ., Bryk, A. S., Jacob, B. A., E aston, J. Q., \& Allensworth, E. (1999). Ending social promotion: Results from the first two years. Chicago: Consortium on Chicago School Research.

Schneider, B ., \& Stevenson, D . (1999). The ambitious generation: America's teenagers motivated but directionless. N ew H aven, CT: Yale University Press.

Sewell, W. H., H aller, A. O ., \& Portes, A. (1969). The educational and early occupational attainment process. American Sociological Review, 34(1), 82-92.

Sewell, W. H ., \& H auser, R. M . (1980). The Wisconsin longitudinal study of social and psychological factors in aspirations and achievements. In A. C. Kerckhoff (E d.), Research in sociology of education and socialization (Vol. 1, pp. 59-99). Greenwich, CT: JAI Press.

Somers, P., C ofer, J., \& VanderPutten, J. (2002). The early bird goes to college: The link between early college aspirations and postsecondary matriculation. Journal of College Student Development, 43(1), 93-107.

Stanton-Salazar, R. D . (1997). A social capital framework for understanding the socialization of racial minority children and youths. Harvard E ducational Review, 67(1), 1-39.

U .S. D epartment of E ducation. (2001a). Digest of education statistics 2000. Washington, D C: U .S. D epartment of E ducation, N ational Center for E ducational Statistics.

U.S. D epartment of E ducation. (2001b). Funding your education. Washington, D C: U.S. D epartment of E ducation, Student F inancial Assistance.

U.S. D epartment of E ducation. (2001c). The condition of education 2001. Washington, D C: U.S. Government Printing Office.

U.S. D epartment of H ealth and H uman Services. (1995). A dolescent time use, risky behavior, and outcomes: An analysis of national data. Washington, DC: Author.

Van de Water, G. S., \& Rainwater, T. (2001). What is P-16 education? A primer for legislators. D enver, CO: E ducation Commission of the States. 
Wells, A. S., \& Crain, R. L. (1994). Perpetuation theory and the long-term effects of school desegregation. Review of Educational Research, 64(4), 531-555.

Wimberly, G . L. III (2000). Links between social capital and educational attainment among African American adolescents. Dissertation Abstracts I nternational, 61(03), 1172. (UMI N 0. 9965178).

Youniss, J., \& Yates, M . (1997). Community service and social responsibility in youth. Chicago: The University of Chicago Press. 